\title{
SCIAMACHY validation by aircraft remote sensing: design, execution, and first measurement results of the SCIA-VALUE mission
}

\author{
A. Fix ${ }^{1}$, G. Ehret ${ }^{1}$, H. Flentje ${ }^{1}$, G. Poberaj ${ }^{1,{ }^{*}}$, M. Gottwald ${ }^{2}$, H. Finkenzeller ${ }^{3}$, H. Bremer ${ }^{4}$, M. Bruns ${ }^{4}$, J. P. Burrows ${ }^{4}$, \\ A. Kleinböhl ${ }^{4}$, H. Küllmann ${ }^{4}$, J. Kuttippurath ${ }^{4}$, A. Richter ${ }^{4}$, P. Wang ${ }^{4}$, K.-P. Heue ${ }^{5}$, U. Platt ${ }^{5}$, I. Pundt ${ }^{5}$, and \\ T. Wagner ${ }^{5}$ \\ ${ }^{1}$ Institut für Physik der Atmosphäre, DLR Oberpfaffenhofen, Germany \\ ${ }^{2}$ Deutsches Fernerkundungsdatenzentrum, DLR Oberpfaffenhofen, Germany \\ ${ }^{3}$ Flugbetrieb, DLR Oberpfaffenhofen, Germany \\ ${ }^{4}$ Institut für Umweltphysik, Universität Bremen, Germany \\ ${ }^{5}$ Institut für Umweltphysik, Universität Heidelberg, Germany \\ *now at: Swiss Federal Institute of Technology Zurich, Institute of Quantum Electronics, Zurich, Switzerland
}

Received: 9 August 2004 - Published in Atmos. Chem. Phys. Discuss.: 15 December 2004

Revised: 17 March 2005 - Accepted: 18 March 2005 - Published: 31 May 2005

\begin{abstract}
For the first time three different remote sensing instruments - a sub-millimeter radiometer, a differential optical absorption spectrometer in the UV-visible spectral range, and a lidar - were deployed aboard DLR's meteorological research aircraft Falcon 20 to validate a large number of SCIAMACHY level 2 and off-line data products such as $\mathrm{O}_{3}, \mathrm{NO}_{2}$, $\mathrm{N}_{2} \mathrm{O}, \mathrm{BrO}, \mathrm{OClO}, \mathrm{H}_{2} \mathrm{O}$, aerosols, and clouds. Within two validation campaigns of the SCIA-VALUE mission (SCIAMACHY VALidation and Utilization Experiment) extended latitudinal cross-sections stretching from polar regions to the tropics as well as longitudinal cross sections at polar latitudes at about $70^{\circ} \mathrm{N}$ and the equator were generated. This contribution gives an overview over the campaigns performed and reports on the observation strategy for achieving the validation goals. We also emphasize the synergetic use of the novel set of aircraft instrumentation and the usefulness of this innovative suite of remote sensing instruments for satellite validation.
\end{abstract}

\section{Introduction}

SCIAMACHY (SCanning Imaging Absorption spectroMeter for Atmospheric CHartographY) is one of the 10 instruments aboard Europe's research satellite ENVISAT, which aims at studying the composition of the Earth's atmosphere from

Correspondence to: A. Fix

(andreas.fix@dlr.de) space. The instrument is a successor of the GOME experiment (Burrows et al., 1999) and was jointly developed by The Netherlands, Belgium and Germany as their national contribution to the ESA ENVISAT programme. SCIAMACHY measures electromagnetic radiation from the near ultraviolet to the near infrared spectral region. Along one orbit, the instrument alternates between nadir and limb measurements observing the radiation scattered or transmitted by the atmosphere. Solar and lunar occultation measurements are also performed where possible. Inversion of the measured spectra yields the amounts and distributions of a number of mesospheric, stratospheric, and tropospheric constituents (Bovensmann et al., 1999).

The measurements and data products from space-based instruments require dedicated validation, i.e. the assessment of the quality of the data derived from the satellite observations with independent measurements. The validation of the geophysical variables provides feedback to calibration, de-bugging and algorithm improvement of the satellite instrument. Only if the differences observed during validation are within satisfactory limits the process of validation is completed and a final quality statement of the data can be made.

In order to validate vertically resolved satellite data similar measurements obtained by other well-established instruments which are co-located in time and space as closely as possible are needed for a correlative analysis. For the validation of atmospheric chemistry instruments, balloonborne measurements have widely been used to complement

(C) 2005 Author(s). This work is licensed under a Creative Commons License. 
Table 1. Validation of spaceborne atmospheric chemistry instruments using aircraft. It is distinguished between airborne in-situ and remote sensing instruments. The remote sensing instruments (in bold) are categorized as far-infrared (FIR), mid-infrared (MIR) or lidar (LIDAR).

\begin{tabular}{|c|c|c|c|c|}
\hline Instrument & Aircraft & Species & $\begin{array}{l}\text { Validation } \\
\text { Instruments }\end{array}$ & Reference \\
\hline ATMOS & NASA ER-2 & $\begin{array}{l}\mathrm{N} 2 \mathrm{O}, \mathrm{O} 3, \mathrm{NOy} \\
\mathrm{H} 2 \mathrm{O}, \mathrm{CH} 4, \mathrm{CO}\end{array}$ & In-situ & Chang et al, 1996a+b \\
\hline \multirow{4}{*}{ GOME } & DLR Falcon & $\mathrm{NO}_{2}$ & In-situ & Heland et al., 2002 \\
\hline & DLR Falcon & $\mathrm{H}_{2} \mathrm{O}$ & In-situ & Wagner et al., 2003 \\
\hline & DLR Falcon & NO2, HCHO & In-situ & $\begin{array}{l}\text { Ladstätter-Weißenmayer et } \\
\text { al., } 2003\end{array}$ \\
\hline & $\begin{array}{l}\text { NCAR Electra / G1 } \\
\text { Twin Otter / NOAA P3 }\end{array}$ & NO2, $\mathrm{HCHO}$ & In-situ & Martin et al., 2004 \\
\hline HALOE & NASA ER-2 & $\mathrm{H} 2 \mathrm{O}, \mathrm{CH} 4$ & In-situ & Tuck et al., 1993 \\
\hline \multirow{5}{*}{ ILAS } & DLR Falcon & $\mathrm{O} 3$ & In-situ & Sugita et al., 2002 \\
\hline & DLR Falcon & $\mathrm{O} 3$ & FIR & Sugita et al., 2002 \\
\hline & NASA ER-2 & $\mathrm{H} 2 \mathrm{O}$ & In-situ & Kanzawa et al., 2002 \\
\hline & NASA ER-2 & $\mathrm{N} 2 \mathrm{O}, \mathrm{CH} 4$ & In-situ & Kanzawa et al., 2003 \\
\hline & DLR Falcon & $\mathrm{N} 2 \mathrm{O}$ & FIR & Kanzawa et al., 2003 \\
\hline MAHRSI & DLR Falcon & $\mathrm{OH}$ & FIR & Englert et al, 2000 \\
\hline MAS & DLR Falcon & $\mathrm{ClO}$ & FIR & Feist et al., 2000 \\
\hline \multirow{3}{*}{ MIPAS } & M55-Geophysika & $\begin{array}{l}\mathrm{HNO} 3, \mathrm{~N} 2 \mathrm{O}, \\
\mathrm{CH} 4, \mathrm{O} 3\end{array}$ & In-situ & Heland et al., 2003 \\
\hline & M55-Geophysika & $\begin{array}{l}\text { O3, HNO3, H2O, } \\
\text { N2O, CH4 }\end{array}$ & MIR, FIR & Blom et al, 2003 \\
\hline & DLR Falcon & $\mathrm{H} 2 \mathrm{O}$ & LIDAR & Fix et al. , 2003 \\
\hline \multirow{3}{*}{ MLS } & NASA ER-2 & $\mathrm{ClO}$ & In-situ & Waters et al., 1996 \\
\hline & DLR Falcon & $\mathrm{ClO}$ & FIR & Crewell et al, 1995 \\
\hline & MOZAIC & $\mathrm{H} 2 \mathrm{O}$ & In-situ & Read et al, 2001 \\
\hline \multirow{3}{*}{ MOPITT } & NASA DC-8 & $\mathrm{CO}$ & In-situ & Heald et al., 2003 \\
\hline & NASA DC-8 & $\mathrm{CO}$ & In-situ & Jacob et al., 2003 \\
\hline & DLR Falcon & $\mathrm{CO}$ & In-situ & Emmons et al, 2004 \\
\hline \multirow{6}{*}{ POAM III } & NASA DC & $\mathrm{O} 3$ & LIDAR & Schoeberl et al., 2002 \\
\hline & NASA ER-2 & $\mathrm{O} 3$ & In-situ & Schoeberl et al., 2002 \\
\hline & NASA DC-8 & $\mathrm{O} 3$ & LIDAR & Lumpe et al., 2003 \\
\hline & NASA ER-2 & $\mathrm{O} 3$ & In-situ & Lumpe et al., 2003 \\
\hline & MOZAIC & $\mathrm{H} 2 \mathrm{O}$ & In-situ & Lumpe et al., 2003 \\
\hline & MOZAIC & $\mathrm{O} 3$ & In-situ & Prados et al., 2003 \\
\hline
\end{tabular}

ground-based remote sensing (i.e. DOAS, FTIR, lidar, or microwave radiometers). However, the most serious restriction of the validation with balloon soundings is their limited number and thus their limited spatial and temporal coverage.

In contrast to most stratospheric balloons, which can reach higher altitudes at one location, aircraft have the ability to fly for many hours and are thus able to perform flights spanning several thousand kilometers. In addition, aircraft possess high flexibility to achieve close temporal and spatial coincidence with satellite overpasses almost anywhere on the globe and under most weather conditions. When equipped with remote sensing instruments that enable atmospheric profiling, extended 2-dimensional cross-sections can be delivered.
These advantages make aircraft excellent platforms for the validation of satellite instruments. Despite these advantages it is astonishing that, up to now, only a handful of activities employing aircraft have been carried out to validate spaceborne sensors (see Table 1). It is also apparent from Table 1 that in most cases in-situ instruments were used. Only very few examples of validation activities are reported in the literature where remote sensing instruments have been deployed on aircraft such as the NASA DC-8, the DLR Falcon or the M55-Geophysika (Crewell et al., 1995; Englert et al., 2000; Feist et al., 2000; Schoeberl et al., 2002; Sugita et al., 2002; Kanzawa et al., 2003; Lumpe et al., 2003; Fix et al., 2003; Blom et al., 2003). 


\section{SCIAMACHY Altitude Coverage}

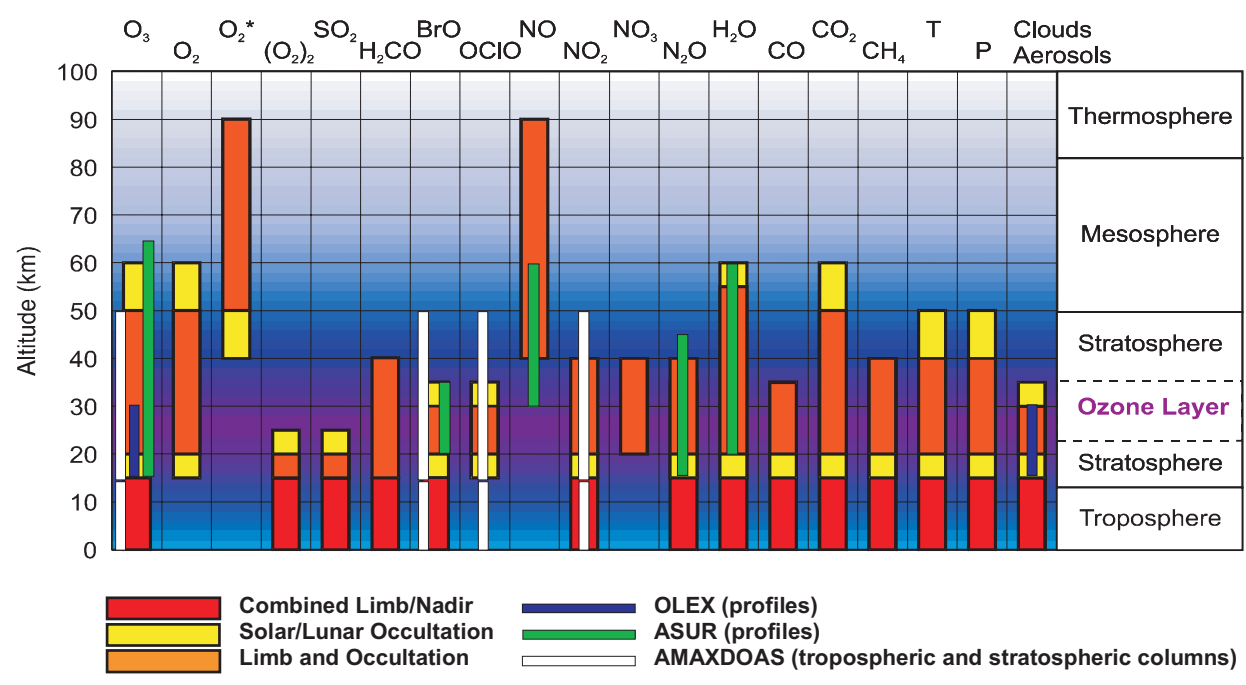

Fig. 1. Target species of the three instruments ASUR, OLEX and AMAXDOAS compared to SCIAMACHY data products. We note that ASUR and OLEX measure profiles while the AMAXDOAS instrument provides stratospheric and tropospheric columns.

Here we report on the novel remote sensing instrumentation that was employed onboard the DLR Falcon during the SCIA-VALUE campaign (SCIAMACHY VALidation and Utilization Experiment) which is part of the German Contribution to the Validation of SCIAMACHY level 2 and off-line data products (GC-VOS). This activity is closely related to balloon-flights and satellite validation also proposed as part of the SCIAMACHY validation effort (Hoogen et al., 1999) and embedded into ESA's programme for the validation of products derived from the ENVISAT Atmospheric Chemistry Instruments.

SCIA-VALUE consisted of a series of validation flights to the northern, mid- and tropical latitudes, which were performed in the first phase of SCIAMACHY validation, during the first year of the instrument's mission. The paper in hand is the introductory paper in a series of results from the SCIA-VALUE campaign. It gives an overview over the performance of the unique remote sensing payload, illuminates the synergetic use of its individual instruments, and describes the campaign activities in detail.

In Sect. 2 the complementary and novel combination of experiments is introduced, which provides validation of SCIAMACHY data products from the mesosphere to the ground. Section 3 describes the flight routes along the ENVISAT orbits which were selected to achieve optimum coincidence with the satellite. In Sects. 4 and 5, new results from combined validation efforts and aspects of synergy are presented.

Specific results from the measurements of the individual instruments will be presented in separate papers within this issue (Kuttippurath et al., submitted, 2004 ${ }^{1}$; Heue et al., 2004) or elsewhere (Fix et al., in preparation, 2004²; Wang et al., in preparation, $2004^{3}$ ).

\section{Validation instruments}

The SCIA-VALUE payload comprised three state-of-the-art experiments for atmospheric sounding:

- The Airborne SUbmillimeter wave Radiometer (ASUR), operated by the University of Bremen.

- The Airborne MultiAXis Differential Optical Absorption Spectrometer (AMAXDOAS) developed and operated jointly by the Universities of Bremen and Heidelberg.

- The Ozone Lidar EXperiment (OLEX) operated by DLR Oberpfaffenhofen.

\footnotetext{
${ }^{1}$ Kuttippurath, J., Kleinböhl, A., Bremer, H., Küllmann, H., Sinnhuber, B.-M., Notholt, J., and Künzi, K.: Seasonal and latitudinal variation of stratospheric ozone and nitrous oxide: Measurements and model calculations, Atmos. Chem. Phys. Discuss., submitted, 2004.

${ }^{2}$ Fix, A., Flentje, H., Ehret, G., et al.: Seasonal and latitudinal variations of ozone and aerosol distributions measured in 2002/2003, in preparation, 2004.

${ }^{3}$ Wang, P., Richter, A., Bruns, M., Burrows, J. P., Heue, K.P., Pundt, I., Wagner, T., and Platt, U.: AMAXDOAS tropospheric $\mathrm{NO} 2$ measurements in cloudy and cloud free situations, in preparation, 2004
} 
Figure 1 summarizes the SCIAMACHY data products measured by the individual instruments. In the following sections a brief description of each instrument and their contribution to SCIAMACHY data validation is given.

\subsection{The ASUR Submillimeter Radiometer}

The Airborne SUbmillimeter Radiometer (ASUR) is a passive heterodyne sensor operating in the frequency range 604$662 \mathrm{GHz}$ (Küllmann et al., 2001). The sensor is characterized by a superconductive low noise mixer, a tunable local oscillator, and two spectrometers: an acousto-optical spectrometer with a bandwidth of $1.5 \mathrm{GHz}$ and a resolution of $1.5 \mathrm{MHz}$, and a chirp-transform spectrometer with a bandwidth of $178 \mathrm{MHz}$ and a resolution of $278 \mathrm{kHz}$. It allows for the spectral detection of stratospheric trace gases like $\mathrm{O}_{3}, \mathrm{~N}_{2} \mathrm{O}, \mathrm{ClO}, \mathrm{HCl}, \mathrm{HNO}_{3}, \mathrm{CH}_{3} \mathrm{Cl}, \mathrm{HO}_{2}, \mathrm{H}_{2} \mathrm{O}, \mathrm{NO}$, and BrO. The pressure broadened lineshape of most of the rotational lines comprises altitude information adequate for a profile retrieval. Observations are made to the right of the aircraft with a constant elevation angle of $12^{\circ}$. Thus, vertical profiles from 15 to over $50 \mathrm{~km}$ altitude can be retrieved for most of the species with a vertical resolution of typically $6 \mathrm{~km}$ in the lower and $12 \mathrm{~km}$ in the upper stratosphere using data from the acousto-optical spectrometer. For ozone the retrieval has recently been extended into the lower mesosphere ( $\sim 65 \mathrm{~km}$ altitude) using data of the chirp-transform spectrometer (Kleinböhl et al., 20044).

ASUR measures volume-mixing-ratio (VMR) profiles along the flight producing 2-D cross sections of stratospheric composition of the above mentioned species. The flexibility of the aircraft allows to investigate small and medium scale spatial variations in the stratosphere closing the gap between locally limited balloon measurements and synoptic satellite data. The high stability and reproducibility of the measurements performed with ASUR make this technique well suited for validation campaigns of spaceborne sensors as successfully done for UARS (MLS, HALOE) ATLAS (MAS), ERS-2 (GOME) and ADEOS (ILAS) (Crewell et al., 1995; Sugita et al., 2002; Kanzawa et al., 2003).

Throughout the SCIAMACHY validation campaign large latitudinal cross sections from the arctic to the tropics as well as longitudinal variations at high latitudes and near the equator were observed (Kuttippurath et al., submitted, 2004 ${ }^{1}$ ). Focus has been set on $\mathrm{O}_{3}$ and $\mathrm{N}_{2} \mathrm{O}$ measurements, other molecules have been observed alternately in between. For ASUR, a quasi operational retrieval is available for $\mathrm{O}_{3}, \mathrm{HCl}$, $\mathrm{ClO}, \mathrm{N}_{2} \mathrm{O}$ and $\mathrm{HNO}_{3}$. For the other molecules, especially $\mathrm{H}_{2} \mathrm{O}$ and $\mathrm{BrO}$ it takes much more effort to produce reliable results. Since ASUR's contribution to the SCIAMACHY

\footnotetext{
${ }^{4}$ Kleinböhl, A., Bremer, H., Sinnhuber, M., Kuttippurath, J., Küllmann, H., Künzi, K., and Notholt, J.: Retrieval of stratospheric and mesospheric ozone profiles from airborne submillimeter measurements, IEEE Trans. Geosci. Remote Sensing, submitted, 2004.
}

validation is mainly $\mathrm{O}_{3}$ and $\mathrm{N}_{2} \mathrm{O}$, only for these molecules the typical resolution and errors are listed in Table 2.

\subsection{The AMAXDOAS instrument}

The Airborne Multi AXis DOAS (AMAXDOAS) instrument observes scattered sunlight in different lines of sight and thus has similarities to the SCIAMACHY instrument. Depending on the viewing direction the light contains specific information on stratospheric or tropospheric absorbers. All light reaching the instrument has passed the stratosphere and therefore shows the absorption structures of the stratospheric trace gases. If the AMAXDOAS instrument flies at tropopause height it will always be possible to detect these absorptions independent of the viewing angle. However, in good approximation, only the nadir viewing telescope detects the tropospheric trace gases.

The AMAXDOAS instrument uses this effect to separate stratospheric columns of different trace gases such as $\mathrm{NO}_{2}$ $\mathrm{O}_{3}$, OClO, $\mathrm{HCHO}$, and $\mathrm{BrO}$. Scattered light is observed using small telescopes mounted outside the aircraft. It is then led to two grating spectrographs via quartz fiber bundles and the analyzed light is detected by 2-D CCD-cameras. Two spectrographs, one for the UV ( $\approx 320$ to $400 \mathrm{~nm}$ ) and one for the visible $(\approx 400$ to $560 \mathrm{~nm}$ ) are required to cover the UV-vis wavelength range and to facilitate better spectral resolution in the UV ( $0.5 \mathrm{~nm}$ instead of $1 \mathrm{~nm}$ as in the visible domain) and also to improve straylight rejection.

According to a theoretical study (Bruns et al., 2004), some profile information can be retrieved from the measurements close to the flight altitude in addition to the separation of stratospheric and tropospheric columns. The best vertical resolution in the upper troposphere and lower stratosphere is achieved with observation lines of sight close to the horizon. Therefore besides the standard lines of sight nadir $\left(-90^{\circ}\right)$ and zenith $\left(+90^{\circ}\right)$ two telescopes pointing at $+2^{\circ}$ and $-2^{\circ}$ of the horizon are used. Measurements in all different viewing directions are taken simultaneously by the CCD cameras.

The data evaluation is based on the Differential Optical Absorption Spectroscopy (DOAS) method which was already described elsewhere (e.g. Platt and Stutz, 2004). For each species, a dedicated wavelength interval is selected (e.g. $332-339 \mathrm{~nm}$ for $\mathrm{O}_{3}$ and $420-444 \mathrm{~nm}$ for $\mathrm{NO}_{2}$ ) and Slant Column Densities (SCD) determined with a nonlinear least squares fit. In a second step, the SCD are converted to Vertical Column Densities (VCD) using airmass factors (AMF) which are either calculated (e.g. Rozanov et al., 2001) or modeled (Friedeburg, 2003; Hönninger et al., 2004). For that purpose some assumptions about the atmosphere are made, e.g. trace gas profiles, ground albedo and cloud coverage.

The measurement principle and viewing geometry of the AMAXDOAS is similar to that of the SCIAMACHY instrument. Therefore, the two instruments observe the same species which is essential for validation. Also, the AMAXDOAS can separate tropospheric and stratospheric columns, 
Table 2. Measurement parameters for the instruments considered in this work.

\begin{tabular}{|c|c|c|c|c|c|c|c|}
\hline \multirow[t]{2}{*}{ Instrument } & \multirow[t]{2}{*}{ Species } & \multirow{2}{*}{$\begin{array}{l}\text { Altitude } \\
\text { Range } \\
{[\mathrm{km}]}\end{array}$} & \multicolumn{2}{|c|}{ Resolution [km] } & \multicolumn{2}{|l|}{ Error } & \multirow[t]{2}{*}{ Reference } \\
\hline & & & Vertical & Horizontal & & & \\
\hline \multirow[t]{5}{*}{ OLEX } & \multirow[t]{2}{*}{$\mathrm{O}_{3}$} & 22 & $<1$ & $<50$ & \multirow{2}{*}{\multicolumn{2}{|c|}{$\begin{array}{l}<4 \% \text { below } 22 \mathrm{~km} \text { (low SZA) } \\
<10 \% \text { below } 22 \mathrm{~km} \text { (high SZA) } \\
<17 \% \text { below } 28 \mathrm{~km} \text { (low } \mathrm{SZA}) \\
<25 \% \text { below } 26 \mathrm{~km} \text { (high SZA) }\end{array}$}} & \multirow[t]{5}{*}{ (Wirth and Renger, 1998) } \\
\hline & & 30 & 1.5 & $<50$ & & & \\
\hline & Aerosol backscatter ratio & 30 & 0.15 & 30 & & $1-10 \%$ (typ. cond.) & \\
\hline & Aerosol optical depth & & & & & $1-10 \%$ (typ. cond) & \\
\hline & Clouds, geometric distribution & 30 & 0.05 & 0.1 & & na. & \\
\hline \multirow[t]{3}{*}{ ASUR } & $\mathrm{O}_{3}$ (stratosphere) & $15-50$ & $6-20$ & 18 & & $>0.3 \mathrm{ppm},<15 \%$ & \multirow{3}{*}{$\begin{array}{l}\text { (Kuttippurath et al.,submitted, } 2004^{1} \text {; } \\
\text { Kleinboehl et al., submitted, } 2004^{4} \text { ) }\end{array}$} \\
\hline & $\mathrm{O}_{3}$ (mesosphere) & $<65$ & $12-20$ & $40-150$ & & $>0.3 \mathrm{ppm},<25 \%$ & \\
\hline & $\mathrm{N}_{2} \mathrm{O}$ & $15-45$ & $8-16$ & 30 & & $>30 \mathrm{ppm},<15 \%$ & \\
\hline \multirow[t]{5}{*}{ AMAXDOAS } & $\mathrm{O}_{3}$ & & column & $<50$ & \multicolumn{2}{|l|}{$5 \%$} & \multirow[t]{5}{*}{ (Wagner et al., 2001) } \\
\hline & $\mathrm{NO}_{2}$ & & $\begin{array}{l}\text { stratospheric/ } \\
\text { tropospheric column }\end{array}$ & $<25$ & $\begin{array}{l}15 \% / \\
10 \%\end{array}$ & $\begin{array}{l}1 \mathrm{e} 15 \mathrm{molec} / \mathrm{cm}^{2} \text { (det. limit)/ } \\
1 \mathrm{e} 15 \mathrm{molec} / \mathrm{cm}^{2} \text { (det. limit) }\end{array}$ & \\
\hline & \multicolumn{2}{|l|}{$\mathrm{BrO}$} & $\begin{array}{l}\text { stratospheric/ } \\
\text { tropospheric column }\end{array}$ & $<50$ & $\begin{array}{l}25 \% / \\
20 \%\end{array}$ & $\begin{array}{l}3 \mathrm{e} 13 \mathrm{molec} / \mathrm{cm}^{2} \text { (det. limit)/ } \\
1 \mathrm{e} 13 \mathrm{molec} / \mathrm{cm}^{2} \text { (det. limit) }\end{array}$ & \\
\hline & \multicolumn{2}{|l|}{$\mathrm{OClO}$} & $\begin{array}{l}\text { stratospheric } \\
\text { slant column }\end{array}$ & $<100$ & $20 \%$ & $5 \mathrm{e} 13 \mathrm{molec} / \mathrm{cm}^{2}$ (det. limit) & \\
\hline & \multicolumn{2}{|l|}{$\mathrm{SO}_{2}$} & tropospheric column & $<50$ & $20 \%$ & $1 \mathrm{e} 16 \mathrm{molec} / \mathrm{cm}^{2}$ (det. limit) & \\
\hline
\end{tabular}

and thereby provide direct validation of one of the key products of the novel limb-nadir matching capability from SCIAMACHY. The similarity of the two measurement systems also allows for direct comparison of lower level products such as slant columns and radiances which is a valuable addition to standard validation activities. However, this also implies that those aspects that are similar in the data analysis of the two instruments (such as the basic DOAS approach) can not be considered as independent validation.

A precursor instrument of AMAXDOAS was successfully applied for measuring $\mathrm{O}_{3}, \mathrm{NO}_{2}$ and $\mathrm{OClO}$ on board of a Transall aircraft during SESAME in 1995 (Pfeilsticker et al., 1997). An overview over the measurement parameters of AMAXDOAS is given in Table 2.

\subsection{The OLEX lidar}

The OLEX system measures the atmospheric backscatter at four wavelengths $308,355,532$, and $1064 \mathrm{~nm}$ with the additional capability to measure the cross-polarized return at $532 \mathrm{~nm}$ for particle phase discrimination. The three wavelengths at 1064, 532, and $355 \mathrm{~nm}$ are generated by a Qswitched Nd:YAG laser with harmonic generation having a total average power of $\sim 4 \mathrm{~W}$ at a repetition rate of $10 \mathrm{~Hz}$. The 308-nm radiation is generated by a $\mathrm{XeCl}$ excimer laser. Specifically for this campaign, a new excimer laser (TUI Laser $\mathrm{GmbH}$ ) was employed that can be operated at a repetition rate of up to $200 \mathrm{~Hz}$ (and an average power of up to $2.4 \mathrm{~W}$ ) and replaced the formerly used 10-Hz system (Wirth and Renger, 1998). The new laser needs much less maintenance and is therefore much more appropriate for such an ambitious and time critical campaign to remote locations.

The receiver system uses a 35-cm Cassegrainian telescope. The received light is split into four channels, one for each wavelength. The 532-nm channel is further divided to subchannels for depolarization detection. The backscattered light at $1064 \mathrm{~nm}$ is detected by means of a silicon avalanche photodiode (APD), whereas the light at the shorter wavelengths is measured by photo-multiplier tubes (PMT). In order to suppress the solar background radiation, adequate bandpass filters are placed in front of the detectors. The signals are digitized with a resolution of 14 bit at a sampling rate of $10 \mathrm{MHz}$ and are interfaced to the data acquisition system and stored together with housekeeping and aircraft data.

OLEX is zenith viewing and its measurement range extends from about $2 \mathrm{~km}$ above flight altitude to about $30 \mathrm{~km}$. The system provides high resolution two-dimensional cross sections of ozone number densities, aerosol extinction, color ratio and particle depolarization. In addition, cirrus or polar stratospheric cloud (PSC) cover information is determined.

The ozone distribution is calculated from the $308 \mathrm{~nm}$ (absorbing wavelength) and $354 \mathrm{~nm}$ (non-absorbing wavelength) return signals using the well established differentialabsorption lidar (DIAL) technique. Over the whole measurement range the vertical resolution of the ozone distribution is less than $1.5 \mathrm{~km}$, thus the vertical resolution of OLEX is much better than the resolution of the SCIAMACHY data products in the limb sounding geometry $(\sim 3 \mathrm{~km})$. In addition, the narrow field of view $(\sim 1 \mathrm{mrad})$ and signal integration of typically $4 \mathrm{~min}$ give a footprint of about $50 \mathrm{~km}$ along track (in flight direction) and $20 \mathrm{~m}$ across track.

A key element for the validation are the aerosol extinction profiles not available from other instruments. For the DOAS retrieval aerosol extinction data is needed to derive the AMF (see also Sect. 5). Besides ozone and aerosol optical properties, PSCs and cirrus clouds are also addressed by the OLEX instrument. The typical resolution of the parameters derived is listed in Table 2. It should be noted that the values for 


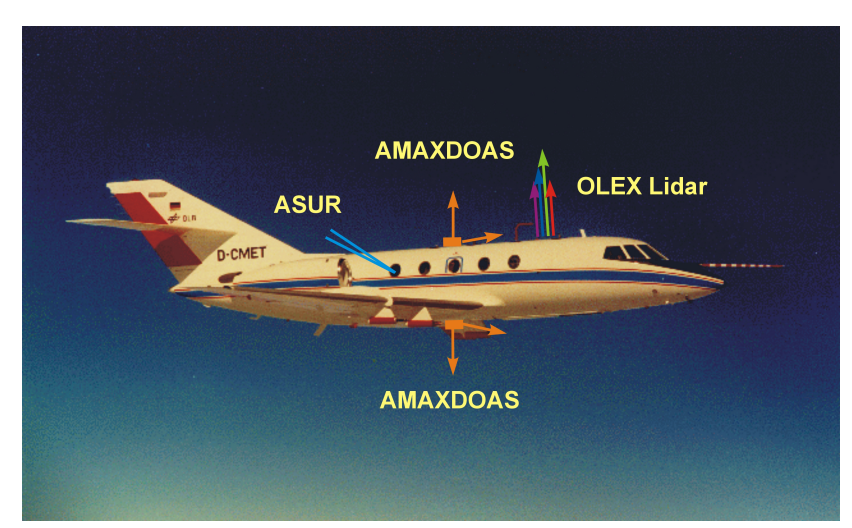

Fig. 2. The German Aerospace Center's meteorological research aircraft Falcon 20 equipped with the three remote sensing instruments ASUR, AMAXDOAS, and OLEX for airborne validation of SCIAMACHY data products $\mathrm{O}_{3}, \mathrm{~N}_{2} \mathrm{O}, \mathrm{NO}_{2}, \mathrm{BrO}, \mathrm{H}_{2} \mathrm{O}, \mathrm{OClO}$, and cloud and aerosol optical properties.

the resolution are much better, both horizontally and vertically, than the required resolution for SCIAMACHY. In order to match the SCIAMACHY resolution the airborne lidar data can be averaged over a larger vertical or horizontal range whereby the precision is generally enhanced.

The OLEX system presently operated on the Falcon employs state-of-the-art technology, which has already shown its excellent performance in a number of national and international campaigns. OLEX was successfully flown during EASOE, and SESAME on board of a Transall aircraft (Wirth and Renger, 1998; Carslaw et al., 1998; Flentje et al., 2000) and recently during THESEO on the Falcon (Flentje et al., 2002, 2003; Peter et al., 2003).

\subsection{Validation instruments on the DLR Falcon}

The meteorological research aircraft Falcon 20 (D-CMET) operated by the German Aerospace Center (DLR) was selected as the instrument platform. Many features make the Falcon an excellent aircraft for the validation experiment. Three large optical windows (diameter $40 \mathrm{~cm}$ ) two in the bottom and one in the roof enable operation of large lidar experiments both for tropospheric (nadir-viewing) and stratospheric (zenith viewing) research. Specially manufactured polyethylene windows allow remote sensing in the microwave spectral region. The aircraft carries a data acquisition system and an extensive instrument package capable of measuring position, altitude, static pressure and temperature. The aircraft has a maximum endurance of $5 \mathrm{~h}$ and a maximum operating altitude of $45000 \mathrm{ft}(\sim 13 \mathrm{~km})$. Figure 2 depicts the viewing geometry of the validation instruments on the Falcon. The ASUR instrument uses a side-ward looking viewing geometry at zenith angle of $78^{\circ}$. This enables atmospheric profiling from about $15 \mathrm{~km}$ up to $65 \mathrm{~km}$ altitude. The AMAXDOAS instrument uses two view ports one on the roof and the other one on the bottom for simultaneously sounding the atmosphere above and below the Falcon aircraft. Each of the ports consist of five telescopes but only the viewing angles of $2^{\circ}$ and $90^{\circ}$, respectively, were utilized here. The OLEX lidar uses the large optical window on the roof of the Falcon for measurements in the stratosphere. The Falcon payload is shown in Fig. 3.

Figure 4 indicates the footprint of the three airborne instruments crossing the footprint of the SCIAMACHY sensor. The AMAXDOAS footprint for the troposphere is of the order of $1 \mathrm{~km}$ across-track and several $\mathrm{km}$ along track depending on solar position. Therefore, the data have to be averaged for direct comparison with SCIAMACHY products. The measurement volume for the stratosphere depends on the solar zenith angle and is close to the aircraft position at high sun but can be displaced towards the sun by up to $100 \mathrm{~km}$ at twilight. As both, SCIAMACHY and AMAXDOAS observe scattered sunlight, the displacement is similar for both instruments. Because of the higher sampling characteristics of the OLEX system in the vertical direction, as mentioned above, vertical averaging of OLEX data is needed in order to match with the vertical resolution of SCIAMACHY data products in the limb sounding geometry which is about $3 \mathrm{~km}$. On the other hand, the narrow field of view ( $\sim 1 \mathrm{mrad})$ and signal integration of about 4 min results in a footprint of about $50 \mathrm{~km}$ along track (in flight direction) and $20 \mathrm{~m}$ across track, only. For the ASUR instrument the situation is somewhat different. In cross track direction the footprint ranges from 14-200 km caused by the special viewing geometry. The along track spatial resolution depends on the integration time for the individual data product. For ozone this is about $18 \mathrm{~km}(40 \mathrm{~km}$ in the mesosphere). Both, OLEX and ASUR, provide profiles for intercomparison over a height range of $\sim 15-30 \mathrm{~km}$.

\section{Field campaigns}

Two field campaigns were performed with the goal to cover measurements at various geophysical locations from low to high latitudes and at different seasons. These two campaigns took place in September 2002 (about six month after the launch of ENVISAT) and February-March 2003, respectively. At these times of the year homogeneous atmospheric conditions can be anticipated which are advantageous for the validation effort particular in view of the different footprints of the validation instruments. The flight routes were selected to cover both, extended longitudinal cross-sections as well as flight legs in the east west direction at high latitudes, where more than one adjacent orbit of SCIAMACHY could be linked, and also at the equator. Logistic reasons constituted additional boundary conditions for the flight pattern. This concerned safe aircraft operation, ground support, as well as reliable supply of cryogenic liquids needed for the operation of ASUR. The flight planning was based on the predicted overpass tables provided by the SCIAMACHY 

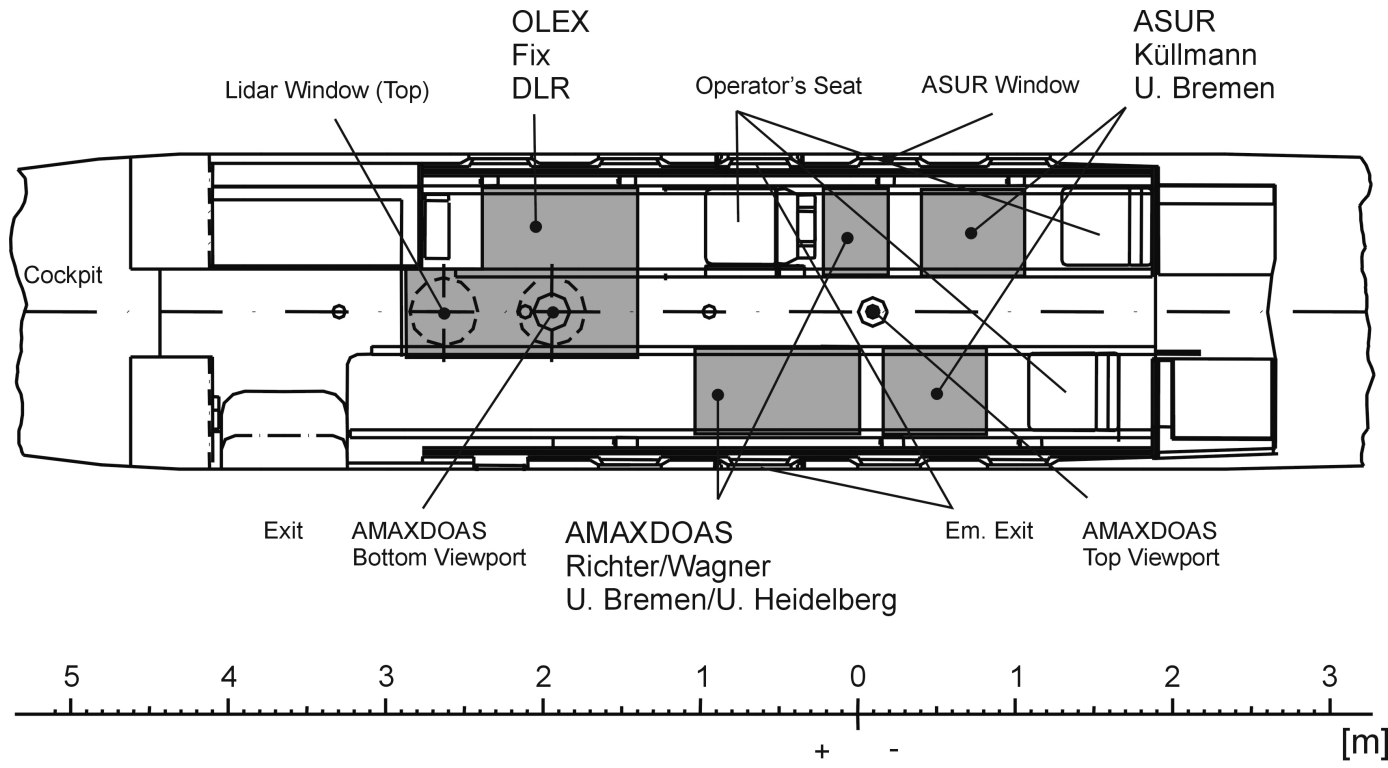

Fig. 3. Falcon aircraft payload during SCIA-VALUE.

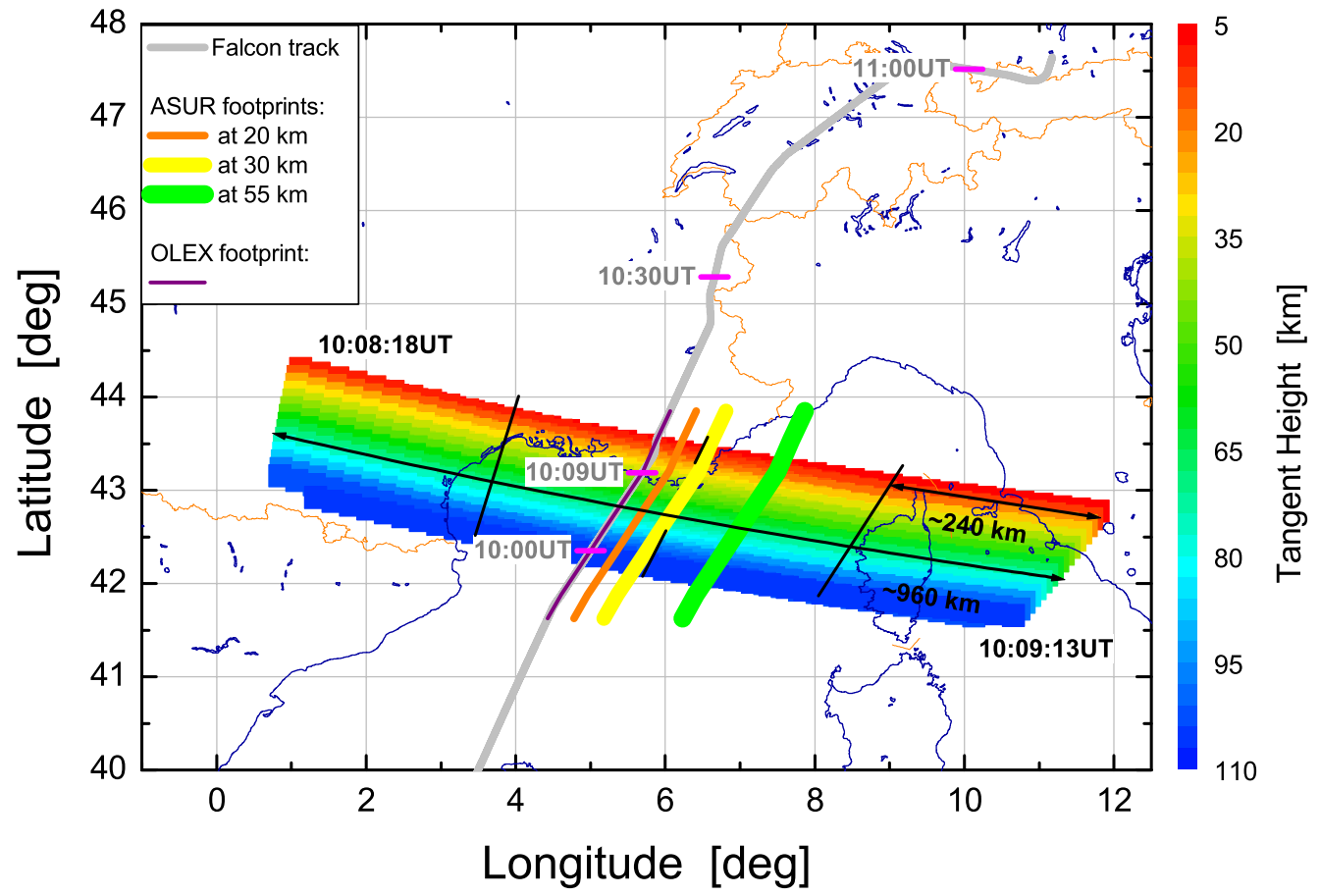

Fig. 4. The panel gives an indication of the footprints of OLEX and ASUR in relation to the SCIAMACHY limb measurements. On 28 September 2002, the Falcon crossed a SCIAMACHY pixel (Orbit No. 3025, state index 12) near Marseille, France, in northerly direction (gray line with time markers). At each tangent height of the SCIAMACHY measurement (height step $=3 \mathrm{~km}$ ) the total swath of $960 \mathrm{~km}$ is divided into 4 separate measurements (read-outs) of $\sim 240 \mathrm{~km}$ width. Details on the viewing geometry of SCIAMACHY can be found in (Bovensmann et al., 1999).

OLEX is zenith viewing. Due to its narrow field of view and a signal integration time of 4 min its footprint is $\sim 50 \mathrm{~km}$ along track and $20 \mathrm{~m}$ across track, only. For ASUR the situation is somewhat different due to its elevation angle of $12^{\circ}$. In cross track direction the footprint thus ranges from 14-200 km which is indicated in the panel for three different heights of $20 \mathrm{~km}, 30 \mathrm{~km}$, and $55 \mathrm{~km}$, respectively. The along track spatial resolution for ozone is about $18 \mathrm{~km}$. For the AMAXDOAS footprint, see text. 
Table 3. Summary of validation activity during the first SCIA-VALUE campaign in September 2002. The orbit index is related to limb observation.

\begin{tabular}{|c|c|c|c|c|c|}
\hline Date & Orbit & $\begin{array}{c}\text { Crossed } \\
\text { Orbit Index }\end{array}$ & Flight Leg & $\begin{array}{c}\text { Departure } \\
\text { [UTC] }\end{array}$ & $\begin{array}{l}\text { Arrival } \\
\text { [UTC] }\end{array}$ \\
\hline \multicolumn{6}{|c|}{ Northern Part } \\
\hline 2002-09-03 & 2667 & $10,11,12$ & $\begin{array}{l}\text { Oberpfaffenhofen - } \\
\text { Kiruna }\end{array}$ & 08:00 & $10: 30$ \\
\hline 2002-09-04 & 2685, 2686 & 7,5 & $\begin{array}{l}\text { Kiruna - Ny-Ålesund } \\
\text { - Kiruna }\end{array}$ & $16: 00$ & 19:30 \\
\hline 2002-09-05 & 2696, 2697 & 10,11 & Kiruna - Keflavik & $10: 00$ & $13: 00$ \\
\hline 2002-09-06 & 2712,2713 & 10,11 & $\begin{array}{l}\text { Keflavik - } \\
\text { Kangerlussuaq }\end{array}$ & $12: 50$ & $15: 00$ \\
\hline 2002-09-07 & 2726, 2727 & 10 & $\begin{array}{l}\text { Kangerlussuaq - } \\
\text { Keflavik }\end{array}$ & $12: 30$ & $14: 30$ \\
\hline 2002-09-07 & 2730 & $\begin{array}{l}\text { Solar Occ. } \\
61.8^{\circ} \text { lat., } \\
351.9^{\circ} \text { lon. }\end{array}$ & $\begin{array}{l}\text { Keflavik - } \\
\text { Oberpfaffenhofen }\end{array}$ & 18:20 & 22:00 \\
\hline \multicolumn{6}{|c|}{ Southern Part } \\
\hline 2002-09-15 & 2839 & 12 & $\begin{array}{l}\text { Oberpfaffenhofen } \\
\text { Mallorca }\end{array}$ & 09:15 & 11:00 \\
\hline 2002-09-17 & 2867 & $13-17$ & Mallorca -Yaounde & $05: 45$ & $15: 30$ \\
\hline 2002-09-18 & 2880,2881 & 17,18 & Yaounde - Nairobi & 08:30 & $11: 30$ \\
\hline 2002-09-19 & 2894 & 18,19 & Nairobi - Mahé & $05: 00$ & $07: 30$ \\
\hline 2002-09-24 & 2966 & 17,18 & Mahé - Nairobi & $06: 30$ & 08:30 \\
\hline 2002-09-25 & 2981 & 17,18 & Nairobi - Yaounde & $06: 30$ & 09:45 \\
\hline 2002-09-26 & 2996 & $13-16$ & Yaounde - Mallorca & 05:30 & $15: 00$ \\
\hline 2002-09-28 & 3025 & 11,12 & $\begin{array}{l}\text { Mallorca } \\
\text { Oberpfaffenhofen }\end{array}$ & 09:30 & 11:00 \\
\hline
\end{tabular}

Operations Support Team (SOST) (Gottwald et al., 2003). The individual parts of the campaign are briefly described in the following.

\subsection{First validation campaign}

The first main campaign of this validation activity provided extended longitudinal and latitudinal atmospheric cross sections between $79^{\circ} \mathrm{N}-4^{\circ} \mathrm{S}$ and $60^{\circ} \mathrm{W}-55^{\circ} \mathrm{E}$, respectively. Starting from Oberpfaffenhofen near Munich the campaign consisted of a northern part and a southern part. The northern route led from Oberpfaffenhofen to Kiruna, Spitsbergen, Kiruna, Iceland, Greenland, Iceland and back to Oberpfaffenhofen (see Fig. 5a). This part was carried out between 3-7 September 2002. A few days later (15 September) the southern flight route began via Palma de
Mallorca, Djerba, Niamey, Yaounde, Nairobi, Mahé and back and ended on 28 September. The campaign consisted of 14 legs to high and low latitudes each, while instruments collected data along 18 ENVISAT orbits.

In most cases, the aircraft flight plan could be organized in order to obtain very good temporal and spatial coincidence with the SCIAMACHY observations. About 54 flight hours within a period of 25 days have been used in total. A summary of the flight legs, orbits crossed as well as the Falcon departure and arrival times of the first main campaign is given in Table 3. 
September 2002

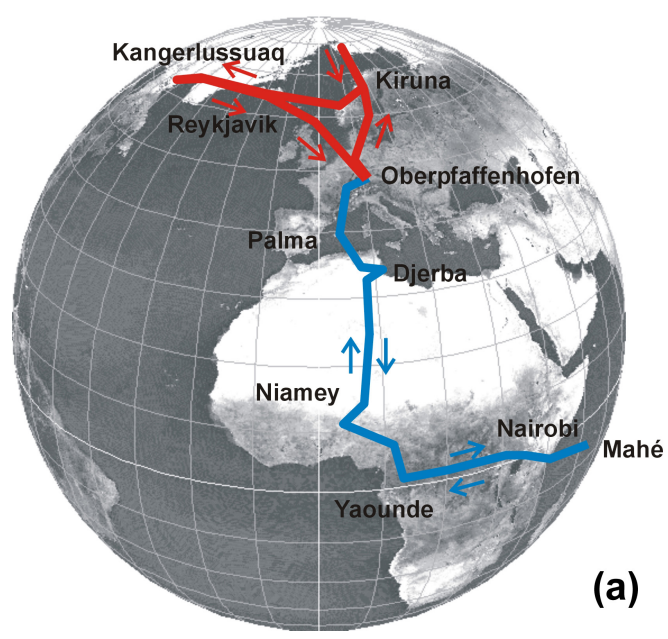

February-March 2003

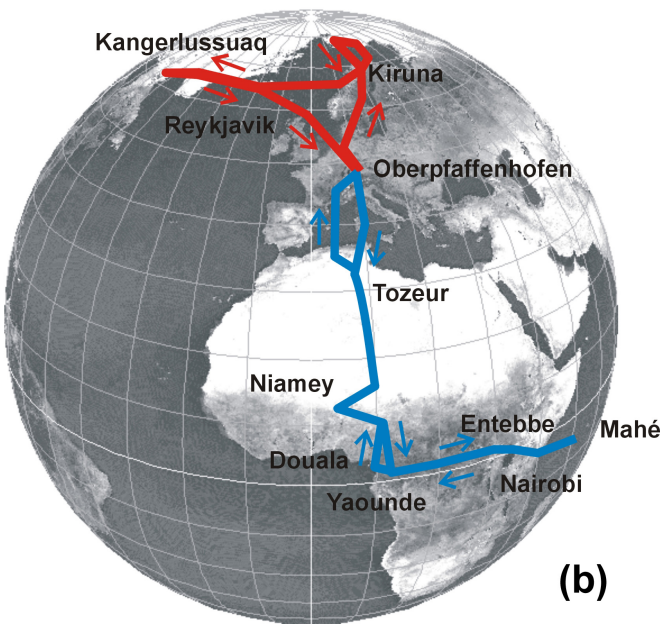

Fig. 5. (a) Northern flight route (red line) from Oberpfaffenhofen-Spitsbergen-Kiruna-Greenland and back on 3-7 September 2002 and southern flight route (blue line) from Oberpfaffenhofen-Yaounde-Nairobi-Mahé and back on 15-28 September 2002. (b) Southern flight route (blue line) from Oberpfaffenhofen-Yaounde-Nairobi-Mahé and back on 19 February-3 March 2002 and northern flight route (red line) from Oberpfaffenhofen-Spitsbergen-Kiruna-Greenland and back on 10-19 March 2003.

\subsection{Second validation campaign}

The second main campaign of this activity consisted of a similar flight pattern as the first one covering longitudes and latitudes between $79^{\circ} \mathrm{N}-4^{\circ} \mathrm{S}$ and $60^{\circ} \mathrm{W}-55^{\circ} \mathrm{E}$, respectively (see Fig. 5b). Starting in Oberpfaffenhofen near Munich on 19 February and ending on 19 March 2003 the campaign consisted of 18 flight legs, again to both arctic and tropical latitudes. The instruments collected data along 16 ENVISAT orbits.

Several problems with either ENVISAT or SCIAMACHY were encountered during this part of the campaign. A failure of ENVISAT on 20 February resulted in a deviation of 1 day from the original flight plan. SCIAMACHY may not have been in the nominal temperature regime on 23 February (Yaounde-Nairobi). SCIAMACHY was out of operation again between 15-19 March. Therefore, an extra flight was performed on 19 March (OberpfaffenhofenOberpfaffenhofen-via northern Denmark) to compensate for the missing orbit.

Several minor deviations from the original flight plan had to be incorporated during the southern part: due to strong headwinds on its way from Yaounde to Nairobi the Falcon had to land for refueling in Entebbe, Uganda, and then continued to Nairobi. On the way to Mahé a technical problem was encountered requesting for a landing in Mombasa, Kenia. Due to strong thunderstorms the Falcon had to land in Douala rather than in Yaounde on its way back. Nevertheless, in most cases a very good temporal and spatial coincidence with the SCIAMACHY observations was achieved.

Concluding the flight operations, about 59 flight hours within a period of 28 days have been used. A summary of the flight legs, orbits crossed, as well as the Falcon departure and arrival times of the 2 nd main campaign are given in Table 4.

\subsection{Summary of Operations}

Altogether, a sum of 113 flight hours was flown within both field campaigns. 49 close SCIAMACHY limb scans were on target. However, taking into account all limb scans within a radius of $1000 \mathrm{~km}$ and a time difference of $<6 \mathrm{~h}$ from the aircraft position this sums up to as many as 99 matches. The distribution of these matches in time and space is depicted in Fig. 6. Approximately the same holds true for SCIAMACHY nadir measurements due to the close relationship between limb and nadir footprints (see e.g. Bovensmann et al., 1999). Additionally, one solar occultation was covered near $62^{\circ} \mathrm{N}$ (see Table 3 ). The additional use of the trajectory hunting technique (Danilin et al., 2002) can even increase the data set suitable for validation. Trajectory hunting is a technique to find air parcels sampled by different platforms over the course of a few days with the help of forward or backward trajectory mapping.

This impressively demonstrates the advantages of airborne validation. Its strong point is the flexibility and the ability to meet many satellite matches along extended longitudinal and latitudinal cross sections in a comparably short time period without being subject to weather conditions on the ground. 
Table 4. Summary of the Falcon flight legs during the second SCIA-VALUE campaign. The orbit index is related to limb observation of SCIAMACHY.

\begin{tabular}{|c|c|c|c|c|c|}
\hline Date & Orbit & $\begin{array}{c}\text { Crossed } \\
\text { Orbit Index }\end{array}$ & Flight Leg & $\begin{array}{c}\text { Departure } \\
\text { [UTC] }\end{array}$ & $\begin{array}{l}\text { Arrival } \\
\text { [UTC] }\end{array}$ \\
\hline \multicolumn{6}{|c|}{ Southern Part } \\
\hline 2003-02-19 & 5086 & 11 & Basel - Tozeur & $8: 00$ & $10: 30$ \\
\hline 2003-02-20 & 5100 & $\mathrm{xx}$ & $\begin{array}{l}\text { Tozeur - Niamey - } \\
\text { Yaounde }\end{array}$ & $7: 30$ & $15: 00$ \\
\hline $2002-02-23$ & 5142 & 16 & $\begin{array}{l}\text { Yaounde - Entebbe- } \\
\text { Nairobi }\end{array}$ & $8: 30$ & $13: 45$ \\
\hline 2003-02-24 & 5156 & 17 & $\begin{array}{l}\text { Nairobi - Mombasa- } \\
\text { Mahé }\end{array}$ & 9:00 & $15: 00$ \\
\hline 2003-02-26 & 5184 & 17 & Mahé - Nairobi & $6: 30$ & 9:00 \\
\hline 2003-02-28 & 5214 & 16 & Nairobi - Douala & $7: 45$ & $12: 00$ \\
\hline 2003-03-01 & 5229 & $13-16$ & $\begin{array}{l}\text { Douala - Niamey - } \\
\text { Tozeur }\end{array}$ & $4: 15$ & $11: 30$ \\
\hline 2003-03-03 & 5258 & 11 & $\begin{array}{l}\text { Tozeur - } \\
\text { Oberpfaffenhofen }\end{array}$ & $8: 30$ & $12: 20$ \\
\hline \multicolumn{6}{|c|}{ Northern Part } \\
\hline 2003-03-10 & 5358 & 9,10 & $\begin{array}{l}\text { Oberpfaffenhofen } \\
\text { Kiruna }\end{array}$ & $9: 45$ & $12: 45$ \\
\hline 2003-03-12 & 5387 & 7,8 & $\begin{array}{l}\text { Kiruna - Ny-Ålesund } \\
\text { - Kiruna }\end{array}$ & $7: 30$ & $11: 15$ \\
\hline 2003-03-13 & 5402 & 9 & Kiruna - Keflavik & 9:30 & $13: 15$ \\
\hline 2003-03-14 & $\begin{array}{l}5417 \\
5418\end{array}$ & $\begin{array}{l}9 \\
9\end{array}$ & $\begin{array}{l}\text { Keflavik } \\
\text { Kangerlussuaq }\end{array}$ & $12: 00$ & $15: 45$ \\
\hline 2003-03-15 & 5433 & $\mathrm{xx}$ & $\begin{array}{l}\text { Kangerlussuaq } \\
\text { Keflavik }\end{array}$ & $13: 00$ & $15: 00$ \\
\hline 2003-03-17 & 5459 & $\mathrm{xx}$ & $\begin{array}{ll}\text { Keflavik } \\
\text { Oberpfaffenhofen }\end{array}$ & $10: 30$ & $14: 15$ \\
\hline 2003-03-19 & 5487 & 10,11 & $\begin{array}{|ll|}\text { Oberpfaffenhofen } & - \\
\text { Oberpfaffenhofen }\end{array}$ & $7: 15$ & 11:00 \\
\hline
\end{tabular}

xx: SCIAMACHY not operating

\section{Data products}

\subsection{AMAXDOAS}

AMAXDOAS spectra in 4 viewing directions were continuously measured in the visible and UV wavelength range during most flights of the campaign. In the Tropics the aircraft cabin temperature was a general problem for all the instruments, and the AMAXDOAS experienced several shutdowns as a result of overheating.

Small data gaps exist during tropical flights whenever the telescope shutters closed to avoid instrument damage when direct sunlight could enter the optics or during those flights when the solar zenith angle was larger than $92^{\circ}$. The quality of the data is generally better at higher latitudes, where the typically larger solar zenith angles lead to larger absorptions and thus better signal to noise ratios.

Exemplary tropospheric columns measured by the AMAXDOAS are shown in Fig. 7. The figure shows the tropospheric vertical columns of $\mathrm{NO}_{2}$ along the flight track on 2 September 2002 from Oberpfaffenhofen to Kiruna. Over Germany, enhanced $\mathrm{NO}_{2}$ columns can clearly be attributed 


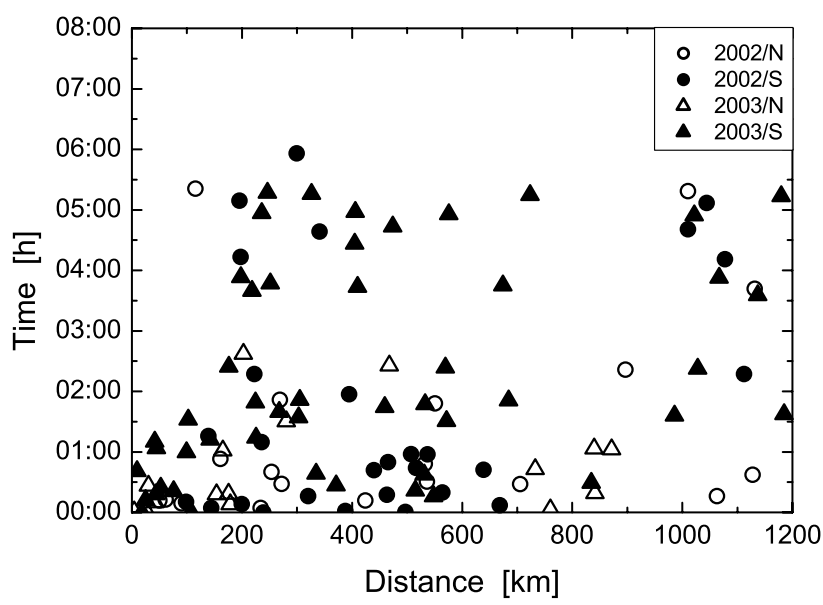

Fig. 6. Time-distance diagram of the coincidences with SCIAMACHY limb scans. Circles and triangles denote the matches in 2002 and 2003, respectively. Open symbols represent the northern parts of the respective flights, the closed ones the southern parts. In total, 99 coincidences were met within the match criteria $(<6 \mathrm{~h}$, $<1000 \mathrm{~km}$ ).

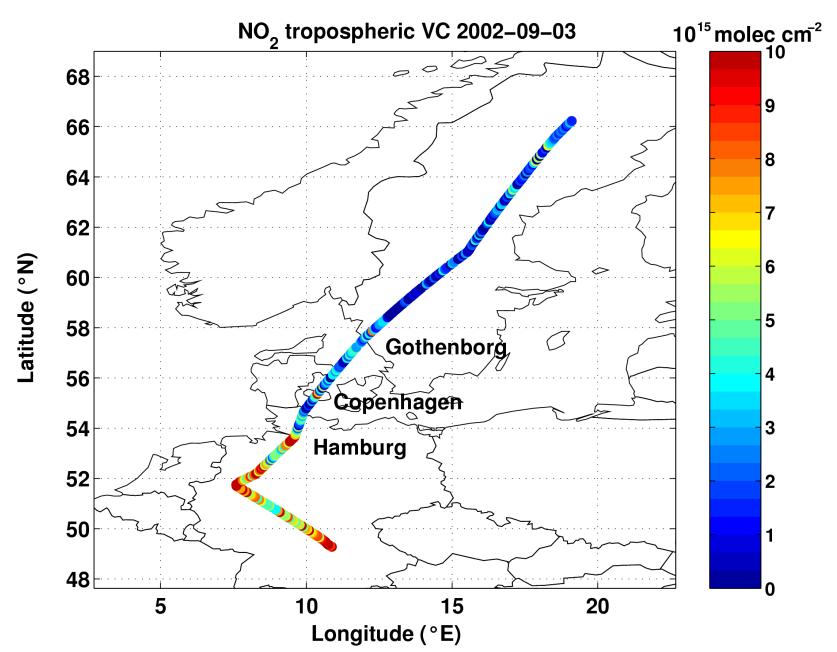

Fig. 7. AMAXDOAS tropospheric $\mathrm{NO}_{2}$ vertical columns along the flight track on 3 September 2002 from Oberpfaffenhofen to Kiruna. Enhanced $\mathrm{NO}_{2}$ columns were observed in regions affected by tropospheric pollution.

to densely populated areas like the Ruhrgebiet and Hamburg. Two smaller peaks were also observed over southern Scandinavia. In Fig. 8 the stratospheric vertical column is plotted together with the tropospheric one. As expected, there is not much variation in the stratospheric signal and all the variations occur in the troposphere.

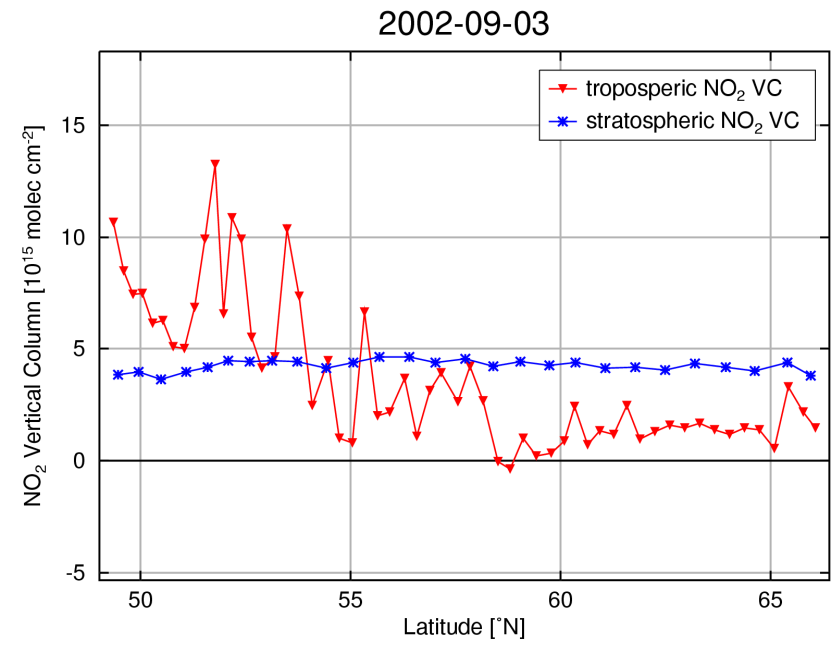

Fig. 8. AMAXDOAS vertical $\mathrm{NO}_{2}$ columns for the stratosphere (blue) and troposphere (red) for the same flight as for Fig. 7. The stratospheric $\mathrm{NO}_{2}$ did not change much during the flight, whereas in the troposphere pollution leads to strongly varying columns.

\subsection{ASUR}

ASUR measured a set of molecules alternately (see Sect. 2.1) on both, the northern and the southern route. During SCIAMACHY overflights the focus has been put on $\mathrm{O}_{3}$ and $\mathrm{N}_{2} \mathrm{O}$. In most cases, several ozone measurements have been accomplished above the area of one SCIAMACHY ground pixel to account for atmospheric variability. Profile comparisons for the $\mathrm{N}_{2} \mathrm{O}$ molecule are also possible for many SCIAMACHY ground pixels at different latitudes. In Fig. 9 typical ozone profiles at tropical and high latitudes, respectively, are shown which are further discussed in Sect. 5. An example of an ASUR $\mathrm{N}_{2} \mathrm{O}$ measurement is depicted in Fig. 10. This measurement was performed on 26 September 2002 and is compared to a nearby profile retrieved from the MIPAS instrument on ENVISAT (ESA operational product IPF V4.61, for a description of the MIPAS instrument see e.g. ESA, 2000). The agreement of the two $\mathrm{N}_{2} \mathrm{O}$ measurements is well within the estimated errors. Frequent measurements of $\mathrm{HNO}_{3}$ during all deployments at all latitudes allow to contribute to the MIPAS validation of $\mathrm{O}_{3}, \mathrm{~N}_{2} \mathrm{O}$, and $\mathrm{HNO}_{3}$ data products as well. In addition, ASUR also measured NO every $10-20^{\circ}$ latitude with reasonable data quality. Several spectra for $\mathrm{H}_{2} \mathrm{O}$ and $\mathrm{BrO}$ were also obtained. However, on 23 February and 3 March 2003 no measurements could be taken due to an unexpected problem with the supply of liquid cryogens in Africa.

\subsection{OLEX}

Profiles of aerosol backscatter and ozone concentration along the flights were measured with the OLEX system during all flights of the campaign. Good measurement conditions, i.e. 

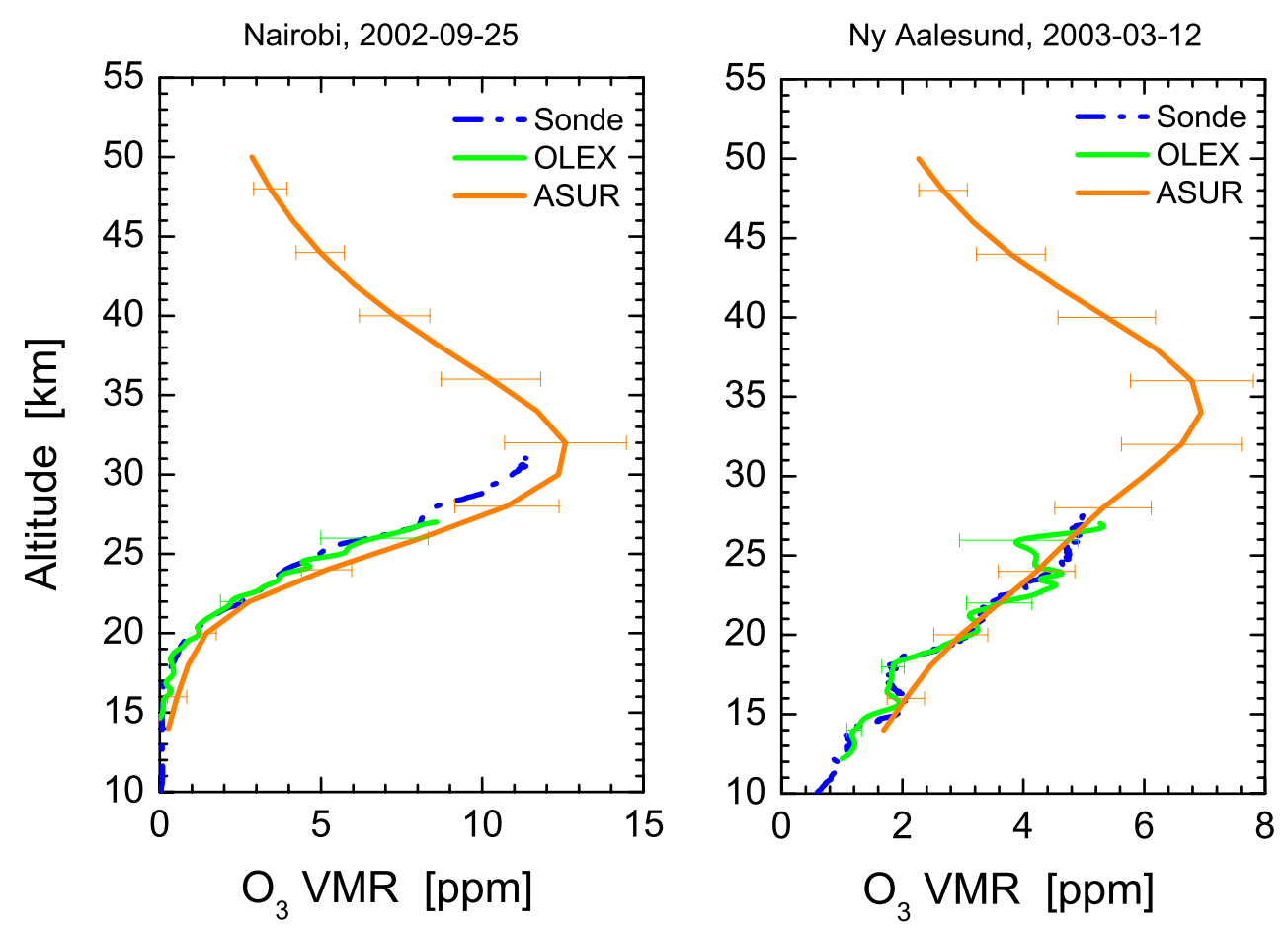

Fig. 9. ASUR, OLEX, and sonde $\mathrm{O}_{3}$ profiles. Ozone sondes were launched in Nairobi $\left(1.27^{\circ} \mathrm{S}, 36.80^{\circ} \mathrm{E}\right)$ at $07: 23 \mathrm{UT}$ and in $\mathrm{Ny} \AA \AA$ lesund $\left(78.93^{\circ} \mathrm{N}, 11.95^{\circ} \mathrm{E}\right)$ at $10: 54 \mathrm{UT}$. Corresponding ASUR measurements including error bars are at 06:52 $\mathrm{UT}^{\circ}\left(0.61^{\circ} \mathrm{S}, 34.60^{\circ} \mathrm{E}\right)$ and at 09:28 UT $\left(78.83^{\circ} \mathrm{N}, 12.42^{\circ} \mathrm{E}\right)$, respectively. OLEX and ASUR profiles were recorded within a time difference of less than 10 min. The integration time was 5 and $2 \mathrm{~min}$, respectively.

no high cirrus above the flight level, prevailed during nearly all northern flights except on the leg from Greenland to Keflavik (7 September 2002), where aviation traffic control restrictions prevented a climb above the cirrus during the first part of the flight over Greenland. On the southern route, particularly in the equator region, the data quality is limited to about $26 \mathrm{~km}$ by the high background solar radiation present around the equinoxes at the local ENVISAT overpass time. Small data gaps exist when the lasers shut off due to overheating which occurred at the very high cabin temperatures encountered during the Sahara transects and when the telescope shutters closed to avoid instrument damage at local noon time. Parts of the flight legs over the African continent were covered by extended layers of thin cirrus clouds at tropopause level.

Representative ozone and backscatter cross-sections measured by OLEX are shown in Figs. 11 and 12. Figure 11 shows the ozone distribution at mid-latitudes for the flight leg on 28 September 2002 that is depicted in Fig. 4. In Fig. 12 the backscatter ratio at $1064 \mathrm{~nm}$ is displayed showing an extended cirrus layer as was often encountered at tropical latitudes during the SCIA-VALUE mission. According to Peter et al. (2003), the small structure at an altitude of $17 \mathrm{~km}$ at $49^{\circ} \mathrm{E}$ is an ultra-thin tropical cirrus cloud (UTTC).

\section{Synergetic use of the instruments}

\subsection{ASUR - OLEX}

ASUR and OLEX are complementary to each other in the sense that the OLEX measurements provide $\mathrm{O}_{3}$ profiles with a higher vertical resolution up to an altitude of $\sim 30 \mathrm{~km}$ whereas the ASUR measurement extends to $50 \mathrm{~km}$ and higher, but, with a somewhat lower vertical resolution (see Table 2). Both measurements can be directly compared over a height range of $15-30 \mathrm{~km}$. A direct comparison of ASUR and OLEX is depicted in Fig. 9 where two OLEX and ASUR measurements are compared to each other and to ozone sondes.

In September 2002 and in March 2003 two ozone sondes were launched near Nairobi, Kenya (Thompson et al., 2003), and near Ny Ålesund, Spitsbergen (von der Gaathen, 2003), suitable for a tentative comparison. The first was launched when the Falcon departed towards Yaounde, Cameroon, and the second during a local flight from Kiruna, Sweden. The corresponding volume mixing ratios are presented in the plots provided. Given are locations (latitude, longitude) and the launch time of the sondes and the measurement time for the Falcon instruments, respectively.

The concurrence of ASUR, OLEX, and sonde measurements is better than $2 \mathrm{~h}$, and the distance is within $300 \mathrm{~km}$. 
The sonde measurements reach up to 31 and $27.5 \mathrm{~km}$ altitude, respectively, and their different shape represents the alteration from tropical to arctic regions. The agreement with the lidar is excellent. The overall agreement with the microwave measurements is also very good and corresponds roughly to the estimated accuracy for ASUR $\mathrm{O}_{3}$ observations of $15 \%$ and $0.3 \mathrm{ppm}$ in the lower stratosphere.

We are well aware that a quantitative comparison between these instruments requires considering their different characteristics particularly their averaging kernels and error covariances as described by Tsou et al. (1995) or Rodgers and Connor (2003). However, a detailed analysis will be subject of a forthcoming paper.

\subsection{AMAXDOAS - OLEX}

The influence of clouds on the tropospheric measurements by the AMAXDOAS instrument have been studied recently (Wang et al., in preparation, 2004 ${ }^{3}$ ). However, even for optically thin and sub-visible clouds AMAXDAOS observations can be affected. The simultaneous lidar measurements allow for quantification of such potential systematic errors. Especially in the Tropics cirrus clouds occur in altitudes higher than the standard flight altitude of the Falcon $(11600 \mathrm{~m})$. Therefore the largest influence can be expected in the zenith viewing direction, and in the following only these data are presented. Usually, cirrus clouds are not taken into account for the simulation of the AMFs.

As an example, we tried to quantify the influence of a thin tropical cirrus cloud encountered on the flight on 19 September 2002. The backscatter ratio of this cloud measured by OLEX can be seen in Fig. 12. The cirrus ranged from $\sim 14 \mathrm{~km}$ up to $\sim 16 \mathrm{~km}$ altitude and extended over a distance of more than $1200 \mathrm{~km}$ from the African continent into the Indian Ocean. The cloud optical thickness (see Fig. 13) was determined calculating the total extinction of the cloud and assuming a height independent lidar ratio. The latter is defined as the ratio of the extinction coefficient to the backscatter coefficient. For tropical cirrus, lidar ratios of the order of $30 \mathrm{sr}$ are reported in the literature (Chen et al., 2002). Using this lidar ratio, the maximum optical thickness $\tau$ of the cirrus reaches 0.04 , thus this cloud is close to the threshold condition for subvisual cirrus ( $\tau=0.03$ ) (Sassen and Cho, 1992). A value of $\tau=0.04$ was therefore used in the following to estimate the cloud effect on the DOAS retrieval.

Figure 14 shows the relative change of the AMFs, modelled with the ray tracing model "Tracy" (Hönninger et al., 2004). It is a direct measure of the cloud's influence on the observation. The data with the cirrus cloud are compared to the standard scenario without the cloud. The calculation was performed for $\lambda=335 \mathrm{~nm}$, which is a typical wavelength for the $\mathrm{O}_{3}$ analysis in the UV. The AMF strongly depends on the Solar Zenith Angle, therefore a SZA range from $1^{\circ}$ to $90^{\circ}$ was simulated.

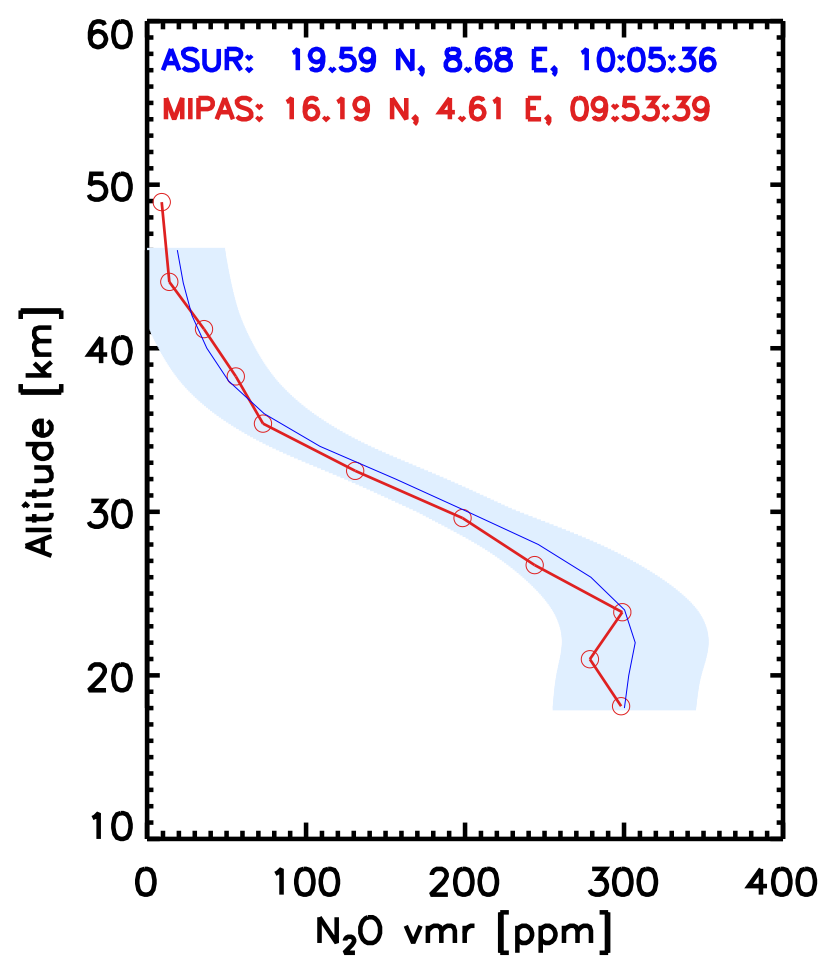

Fig. 10. Typical $\mathrm{N}_{2} \mathrm{O}$ profile as measured by ASUR (blue line) including its error (shaded area). The data was recorded on 26 September 2002 south of the Saharan desert. The red line shows data retrieved from the MIPAS instrument on ENVISAT in comparison. Times and geolocation of the measurements are also given.

In general, the influence of the cirrus clouds is larger for smaller SZAs. For $\mathrm{O}_{3}$ the effect can be as large as $15 \%$. Usually stratospheric UV/vis observations are performed during twilight, and here the influence is negligible.

The observed trend is caused by the different directions the light is scattered into. The phase function of the aerosol forming the cirrus cloud is forward-peaked, whereas for the Rayleigh scattering the phase function is symmetric. At smaller SZAs, the aerosols scatter more sunlight directly into the telescope than in the cloudless case. Here the Rayleigh scattering is dominant, allowing multiple scattering including ground reflection. In total the average optical light path through the atmosphere is shorter in the aerosol case, and thus the AMF decreases.

During the flight on 19 September 2002 the SZA ranged from $62^{\circ}\left(05: 15\right.$ UT) $-19^{\circ}(07: 15$ UT). At the location where the cloud is thickest the SZA amounts to $\sim 57^{\circ}$. From Fig. 14 we therefore anticipate an effect on the VCD of the order of a 5\% underestimation. Figure 13 shows the retrieved ozone vertical column. Indeed, there is a clear tendency towards lower values where the cloud is located. In comparison the vertical column measured by GOME (Burrows et al., 1999) is also shown. Assuming a baseline of the order of $\sim 272 \mathrm{DU}$ the effect of the cloud amounts to up to $\sim 14 \mathrm{DU}$ or $\sim 5 \%$, 


\section{ALR OLXX}

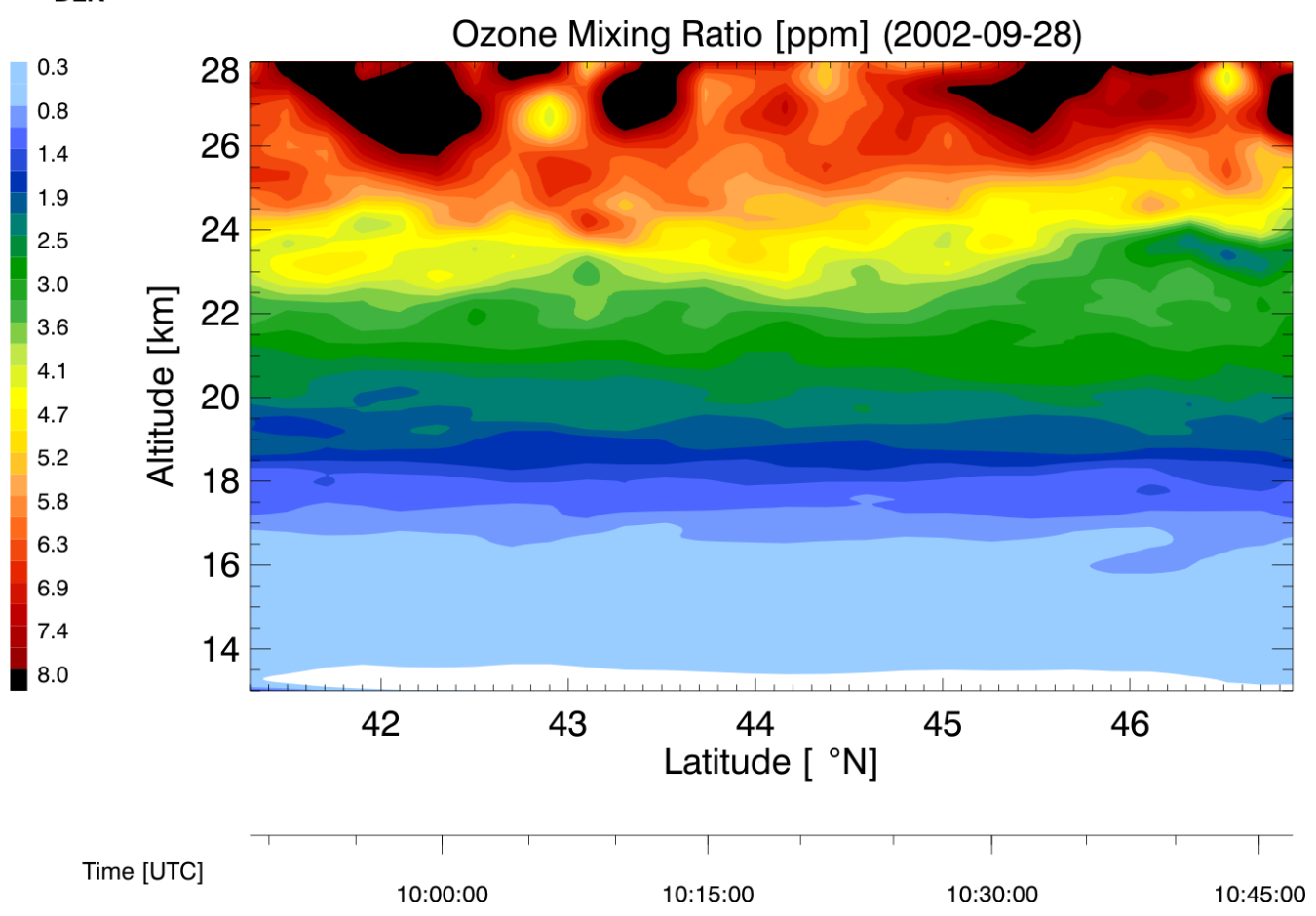

Fig. 11. OLEX measurement of the ozone distribution on the measurement flight on 28 September 2002. The Falcon flight pattern is given in Fig. 4. The overpass of SCIAMACHY took place at 10:09 UTC around $43^{\circ} \mathrm{N}$.

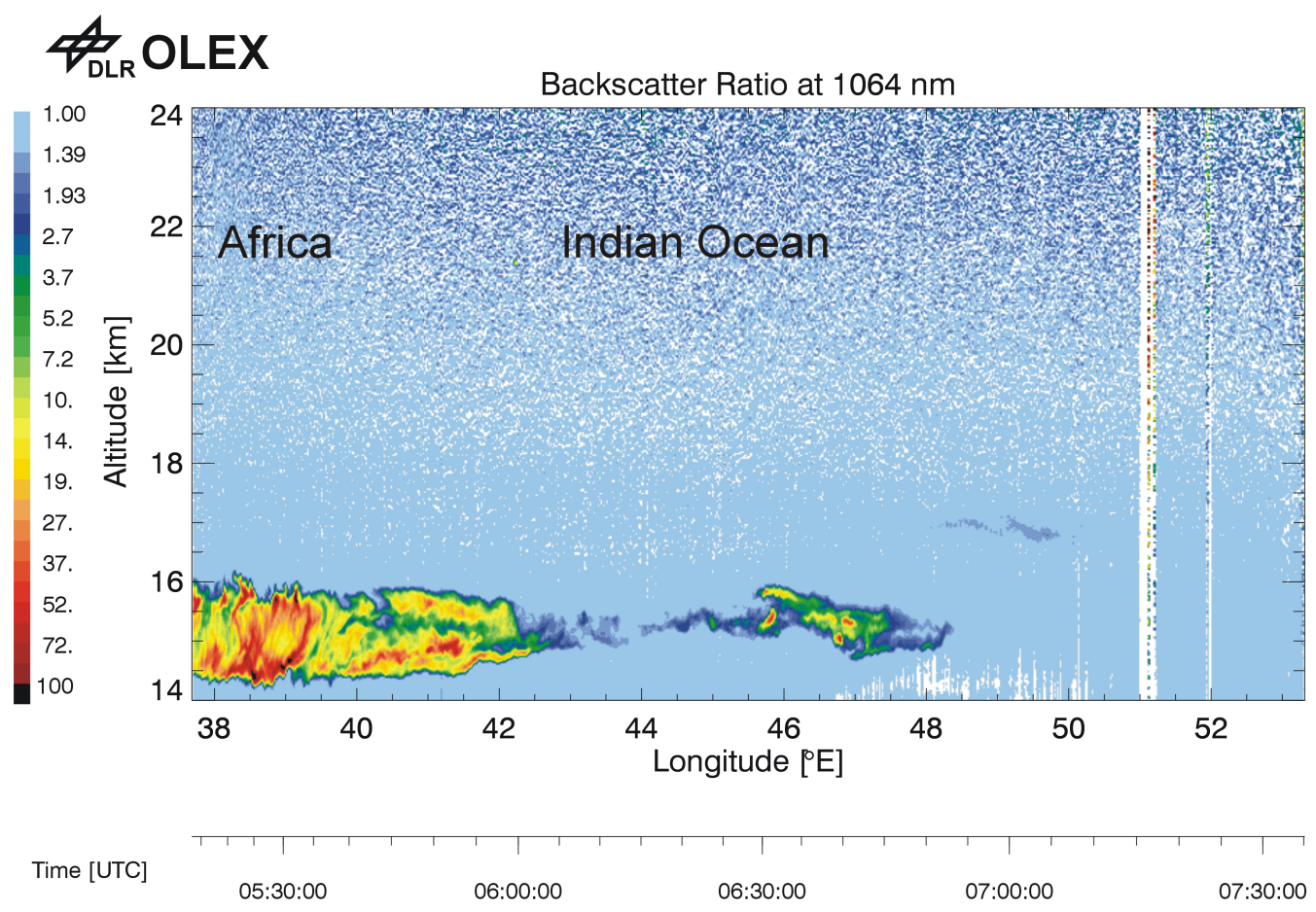

Fig. 12. OLEX measurement of the backscatter ratio at $1064 \mathrm{~nm}$ on the flight of 19 September 2002 from Nairobi to Mahé. An extended thin cirrus layer is seen that extends from the African continent into the Indian Ocean. 


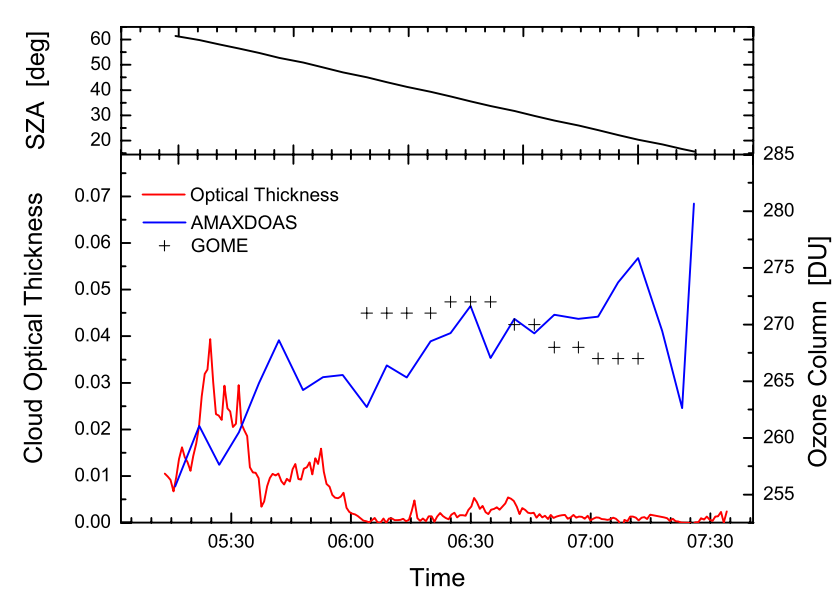

Fig. 13. Optical thickness (red line) of the thin cirrus clouds (see Fig. 12) observed on the flight from Nairobi to Mahé on 19 September 2002 calculated assuming a lidar ratio of $30 \mathrm{sr}$ and the ozone column derived by AMAXDOAS (blue line) for the same flight leg. The crosses denote a corresponding ozone column measurement by GOME. As the solar zenith angle is important to estimate the error in the DOAS retrieval its value along the flight track is given in the upper panel. In the area affected by the cloud, the apparent $\mathrm{O}_{3}$ column is lower by about $5 \%$ in agreement with the estimate based on radiative transfer calculations. For further details, see text.

which is in agreement with our estimate. The high variability in the $\mathrm{O}_{3}$ data observed at this time may also be caused by a variable cloud cover below the aircraft.

In summary, in the presence of high cirrus clouds, the additional information provided by lidar measurements can reduce the systematic error in stratospheric columns retrieved from measurements of the AMAXDOAS measurements for low and medium SZA significantly.

\section{Conclusions}

An airborne mission to validate SCIAMACHY operational level 2 and off-line data products at various geophysical locations and different seasons in the northern hemisphere was performed in the first year of the instrument's mission. For this purpose, the German Aerospace Center's research aircraft Falcon 20 was equipped with a complementary and novel suite of remote sensing instruments which provides validation of the SCIAMACHY data products from the mesosphere to the ground.

During 112 flight hours at high, mid-, and low latitudes, the individual instruments ASUR, AMAXDOAS, and OLEX collected data along 34 ENVISAT orbits. With the help of the SCIAMACHY operations support the aircraft flight plan could be organized in order to obtain very good temporal and spatial coincidence with numerous SCIAMACHY observations. A total of 99 SCIAMACHY limb scans were hit within

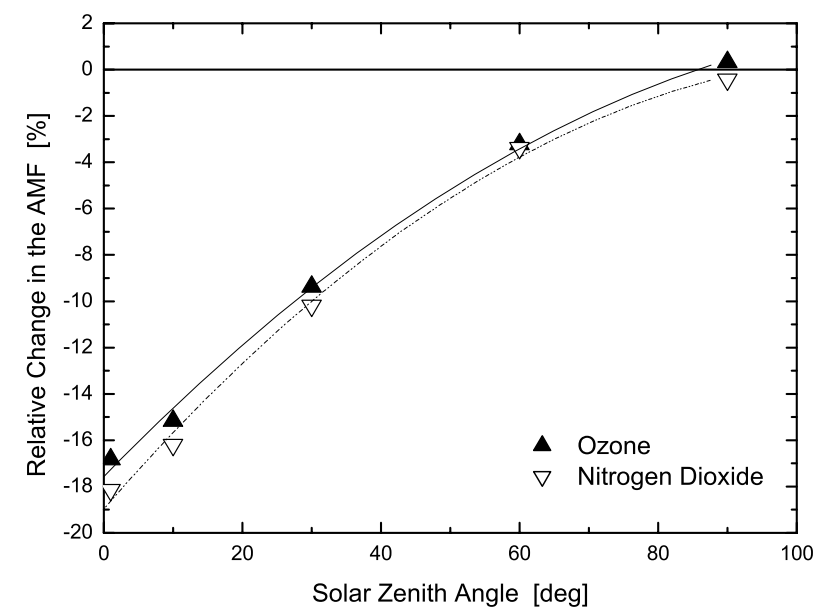

Fig. 14. Relative change of the AMF for stratospheric $\mathrm{O}_{3}$ and $\mathrm{NO}_{2}$ plotted as function of solar zenith angle. The cloud free case was used as norm and the influence of the cirrus clouds is given relative to this value. For a SZA of $57^{\circ}$ a relative change of about $-5 \%$ is given for the $\mathrm{O}_{3}-\mathrm{AMF}$ which results in a $5 \%$ underestimation of the $\mathrm{O}_{3}$ column when neglecting the cirrus cloud.

a time difference of $<6 \mathrm{~h}$ and a radius around the aircraft position of $<1000 \mathrm{~km}$. At the same time, due to the special viewing geometry of SCIAMACHY, many more collocations with the smaller nadir pixels were obtained providing an excellent basis for the validation of tropospheric products.

The DLR Falcon has thus proven to be an excellent platform for extensive validation campaigns in the northern, mid-latitude and tropical regions even under difficult conditions concerning flight operations and logistics.

Since specific results from the measurements of the individual instruments will be presented in separate papers we restricted ourselves to giving a representative overview over the data quality. Also, the validation exercise will be treated in forthcoming papers as soon as the operational data products are available.

In addition, two aspects of the synergetic use of the instruments have been addressed. First, the joint use of ozone profiles derived from ASUR and OLEX results in either higher altitude extension or better vertical resolution than with one of these instruments alone. Second, the information of aerosol or cloud optical thickness derived from the OLEX lidar offers valuable information to reduce the systematic error in the stratospheric column retrieval of AMAXDOAS.

The results obtained during the SCIA-VALUE campaigns impressively demonstrate that an aircraft equipped with this innovative combination of airborne remote sensing instruments is an excellent platform for the validation of satelliteborne atmospheric chemistry instruments as well as for atmospheric case studies. 
Acknowledgements. We would like to thank C. Höglauer and $\mathrm{H}$. Herrmann for assistance during the integration and certification of OLEX's excimer laser system and S. Beringer for helping to quantify the satellite matches. We are pleased to acknowledge G. Näveke for the technical support to ASUR. Many thanks go to R. Rollenbeck and F. Finocchi who have contributed much to the success of the AMAXDOAS project and the workshop at the Institute of Environmental Physics, University of Heidelberg, for the construction of the various parts of the AMAXDOAS instrument. H. Herrmann helped to design the AMAXDOAS rack. The DLR flight department, and in particular H. Brockstieger, assisted during its construction and certification.

Special thanks go to the entire DLR flight department for excellent flight operations and logistics. LSI supported the logistics effectively.

We would also like to thank MeteoSwiss/KMI and AWI for the supply of the ozonesonde data from Nairobi and Ny Ålesund, respectively.

The SCIA-VALUE project is sponsored by DLR Bonn under contracts 50 EE 0023 and 50 EE 0024.

Edited by: M. Dameris

\section{References}

Blom, C. E., Cortesi, U., and Redaelli, G.: ENVISAT validation: Introduction to the correlative measurements by the chemistry payload on board the M-55 Geophysica, 16th ESA Symp.on European Rocket and Balloon Programmes and Related Research, St. Gallen, CH, 2-5 June 2003, ESA SP-530, 503-508, 2003.

Bovensmann, H., Burrows, J. P., Buchwitz, M., Frerick, J., Noël, S., Rozanov, V. V., Chance, K. V, and Goede, A. P. H.: SCIAMACHY-Mission Objectives and Measurement Modes, J. Atmos. Sci., 56, 126-150, 1999.

Bruns, M., Buehler, S. A., Burrows, J. P., Heue, K.-P., Platt, U., Pundt, I., Richter, A., Rozanov, A., Wagner, T., and Wang, P.: Retrieval of Profile Information from Airborne Multi Axis UV/visible Skylight Absorption Measurements, Appl. Opt., accepted, 2004.

Burrows, J. P., Weber, M., Buchwitz, M., et al.: The Global Ozone Monitoring Experiment (GOME): Mission Concept and First Scientific Results, J. Atmos. Sci., 56, 151-175, 1999.

Carslaw, K. S., Wirth, M., Tsias, A., et al.: Increased stratospheric ozone depletion due to mountain-induced atmospheric waves, Nature, 391, 675-678, 1998.

Chang, A. Y., Salawich, R. J., Michelsen, H. A., et al.: A comparison of measurements from ATMOS and instruments aboard the ER 2 aircraft: Tracers of atmospheric transport, Geophys. Res. Lett., 23 (17), 2389-2392, doi:96GL01677, 1996a.

Chang, A. Y., Salawich, R. J., Michelsen, H. A., et al.: A comparison of measurements from ATMOS and instruments aboard the ER 2 aircraft: Halogenated gases, Geophys. Res. Lett., 23 (17), 2393-239, doi:96GL01678, 1996b.

Chen, W. N., Jian, J. W., and Nee, J. B.: Lidar ratio and depolarization ratio of cirrus clouds, Appl. Opt., 41, 6470-6476, 2002.

Crewell, S., Fabian, R., Künzi, K., Nett, H., Wehr, T., Read, W., and Waters, J.: Comparison of ClO-Measurements by Airborne and Spaceborne Microwave Radiometers in the Arctic Winter Stratosphere 1993, Geophys. Res. Lett., 22(12), 1489-1492, 1995.
Danilin, M. Y., Ko, M. K. W., Froidevaux, L., et al.: Trajectory hunting as an effective technique to validate multiplatform measurements: Analysis of the MLS, HALOE, SAGE-II, ILAS, and POAM-II data in October-November 1996, J. Geophys. Res., 107(D20), 4420, doi:10.1029/2001JD002012, 2002.

de Valk, J. P. J. M. M., Goede, A. P. H., de Jonge, A. R. W., et al.: Airborne heterodyne measurements of stratospheric $\mathrm{ClO}, \mathrm{HCl}$, O3, and N2O during SESAME 1 over northern Europe, J. Geophys. Res., 102(D1), 1391-1398, 1997.

Emmons, L. K., Deeter, M. N., Gille, J. C., et al.: Validation of Measurements of Pollution in the Troposphere (MOPITT) CO retrievals with aircraft in situ profiles, J. Geophys. Res., 109, D03309, doi:10.1029/2003JD004101, 2004.

Englert, C. R., Schimpf, B., Birk, M., Schreier, F., Krocka, M., Nitsche, R. G., Titz, R. U., and Summers, M. E: The $2.5 \mathrm{THZ}$ heterodyne spectrometer THOMAS: Measurement of $\mathrm{OH}$ in the middle atmosphere and comparison with photochemical model results, J. Geophys. Res., 105, (D17) 22 211-22 223, 2000.

ESA, ENVISAT-MIPAS: An Instrument for Atmospheric Chemistry and Climate Research, ESA SP-1229, March 2000.

Feist, D. G., C. P. Aellig, P. M. Solomon, J. W. Barrett, S. Zoonematkermani, P. Hartogh, C. Jarchow, and J. W. Waters: Validation of stratospheric $\mathrm{ClO}$ measurements from the Millimeterwave Atmospheric Sounder (MAS), J. Geophys. Res., 105, (D7), 9053-9062, 2000.

Fix, A., Poberaj, G., Kiemle, C., Flentje, H., Busen, R., Fiebig, M., and Ehret, G.: MIPAS Validation with the DLR Falcon, Proc. of Envisat Validation Workshop, Frascati, Italy, 9-13 December 2002, ESA SP-531, August 2003.

Flentje, H. and Kiemle, C.: Erosion and mixing of filaments in the Arctic lower stratosphere revealed by airborne lidar measurements, J. Geophys. Res., 108(D8), 4232, doi:10.1029/2002JD002168, 2003.

Flentje, H., Lahoz, W. A., Renger, W., and Wirth, M.: Validation of Contour Advection simulations with airborne lidar measurements of filaments during the Second European Stratospheric Arctic and Midlatitude Experiment (SESAME), J. Geophys. Res., 105, D12, 15 417-15 437, 2000.

Flentje, H., Dörnbrack, A., Fix, A., Füglistaler, S., Luo, B., Meister, A., Peter, T., and Schmid, H.: Denitrification inside the Stratospheric Vortex in the Winter 1999/2000 by Sedimentation of large NAT-Particles, J. Geophys. Res., 107(D16), doi:10.1029/2001JD001015, 2002.

Gottwald, M., Krieg, E., Döhler, W., Noël, S., and Wuttke, M.: http://atmos.af.op.dlr.de/projects/scops/, 2003.

Heald, C. L., Jacob, D. J., Fiore, A. M., et al.: Asian outflow and trans-Pacific transport of carbon monoxide and ozone pollution: An integrated satellite, aircraft, and model perspective, J. Geophys. Res., 108(D24), 4804, doi:10.1029/2003JD003507, 2003.

Heland, J., Schlager, H., Richter, A., and Burrows, J. P.: First Comparison of tropospheric $\mathrm{NO}_{2}$ column densities retrieved from GOME measurements and in situ aircraft measurements, Geophys. Res. Lett., 29(20) 44-1-44-4, 2002.

Heland, J., Schlager, H., Schiller, C., et al.: Validation of MIPAS on ENVISAT by In Situ Instruments on the M55-Geophysica, Proc. of Envisat Validation Workshop, Frascati, Italy, 9-13 December 2002, ESA SP-531, August 2003.

Heue, K.-P., Richter, A., Wagner, T., Bruns, M., Burrows, J. P., v. Friedeburg, C., Lee, W. D., Platt, U., Pundt, I., and Wang, 
P.: Validation of SCIAMACHY tropospheric NO2-columns with AMAXDOAS measurements, Atmos. Chem. Phys. Discuss., accepted, 2004.

Hönninger, G., v. Friedeburg, C., and Platt, U.: Multi Axis Differential Optical Absorption Spectroscopy (MAX-DOAS), Atmos. Chem. Phys., 4, 231-254, 2004,

SRef-ID: 1680-7324/acp/2004-4-231.

Hoogen, R., Burrows, J. P., Noël, S., Platt, U., and Wagner, T.: SCIAMACHY mission objectives and validation concept: The German contribution, Proc. 14th ESA Symp. on European Rocket and Balloon Programs and Related Research, ESA SP437, September 1999.

Jacob, D. J., Crawford, J. H., Kleb, M. M., Connors, V. S., Bendura, R. J., Raper, J. L., Sachse, G. W., Gille, J. C., Emmons, L., and Heald, C. L.: Transport and Chemical Evolution over the Pacific (TRACE-P) aircraft mission: Design, execution, and first results, J. Geophys. Res., 108(D20), 8781, doi:10.1029/2002JD003276, 2003.

Kanzawa, H., Schiller, C., Ovarlez, J., et al.: Validation and data characteristics of water vapor profiles observed by the Improved Limb Atmospheric Spectrometer (ILAS) and processed with the version 5.20 algorithm, J. Geophys. Res., 107(D24), 8217, doi:10.1029/2001JD000881, 2002.

Kanzawa, H., Sugita, T., Nakajima, H., et al.: Validation and data characteristics of nitrous oxide and methane profiles observed by the Improved Limb Atmospheric Spectrometer (ILAS) and processed with the Version 5.20 algorithm, J. Geophys. Res., 108(D16), 8003, doi:10.1029/2002JD002458, 2003.

Küllmann, H., Bremer, H., Kleinböhl, A., von König, M., and Künzi, K.: The Airborne Submillimeter Radiometer (ASUR) as a tool for stratospheric sensing, edited by: Buehler, S., International Symposium on Sub-Millimeter Wave Earth Observations from Space - III, Logos Verlag Berlin, 15-24, 2001.

Ladstätter-Weißenmayer, A., Heland, J., Kormann, R., v. Kuhlmann, R., Lawrence, M. G., Meyer-Arnek, J., Richter, A., Wittrock, F., Ziereis, H., and Burrows, J. P.: Transport and buildup of tropospheric gases during the MINOS campaign: Comparison of GOME, in-situ aircraft measurements and MATCHMPIC-data, Atmos. Chem. Phys., 3, 1887-1902, 2003,

\section{SRef-ID: 1680-7324/acp/2003-3-1887.}

Lumpe, J. D., Fromm, M., Hoppel, K., et al.: Comparison of POAM III ozone measurements with correlative aircraft and balloon data during SOLVE, J. Geophys. Res., 108, D5, 8316, doi:10.1029/2001JD000472, 2003.

Peter, Th., Luo, B. P., Wirth, M., et al.: Ultrathin Tropical Cirrus Clouds (UTTCs): I Cloud morphology and occurrence, Atmos. Chem. Phys., 3, 1083-1091, 2003,

SRef-ID: 1680-7324/acp/2003-3-1083.

Pfeilsticker, K., Blom, C. E., Brandtjen, R., Fischer, H., Glatthor, N., Grendel, A., Gulde, T., Höpfner, M., Perner, D., Piesch, Ch., Platt, U., Renger, W., Sessler, J., and Wirth, M.: Aircraft-borne Detection of the Stratospheric Column Amounts of $\mathrm{O}_{3}, \mathrm{NO}_{2}$, $\mathrm{OClO}, \mathrm{ClNO}_{3}, \mathrm{HNO}_{3}$ and Aerosols around the Arctic Vortex $\left(79^{\circ} \mathrm{N}\right.$ to $\left.39^{\circ} \mathrm{N}\right)$ during Spring 1993,1 . Observational data, J. Geophys. Res., 102, 10 801-10 814, 1997.

Platt, U. and Stutz, J.: Differential Optical Absorption Spectroscopy, Springer Verlag Heidelberg, 2004.

Prados, A. I., Nedoluha, G. E., Bevilacqua, R. M., Allen, D. R., Hoppel, K. W., and Marenco, A.: POAM III ozone in the up- per troposphere and lowermost stratosphere: Seasonal variability and comparisons to aircraft observations, J. Geophys. Res., 108(D7), 4218, doi:10.1029/2002JD002819, 2003.

Read, W., Waters, J. W., Wu, D. L., et al.: UARS Microwave Limb Sounder upper tropospheric humidity measurement: Method and validation, J. Geophys. Res., 106(D23), 32 207-32 258, 2001.

Rodgers, C. D., and B. J. Connor: Intercomparison of remote sounding instruments, J. Geophys. Res., 108(D3), 4116, doi:10.1029/2002JD002299, 2003.

Rothman, L. S., Rinsland, C. P., Goldman, A., et al.: The HITRAN molecular spectroscopic database and HAWKS (HITRAN Atmospheric Workstation): 1996 edition, J. Quant. Spectrosc. Radiat. Transfer, 60, 5, 665-710, 1998.

Rozanov, A., Rozanov, V., and Burrows, J. P.: A numerical radiative transfer model for a spherical planetary atmosphere: combined differential integral approach involving the Picard iterative approximation, J. Quant. Spectrosc. Radiat. Transfer 69, 491-512, 2001.

Sassen, K. and Cho, B. S.: Subvisible-thin cirrus lidar dataset for satellite verification and climatological research, J. Appl. Meteor., 31, 1275-1285, 1992.

Schoeberl, M. R., Newman, P. A., Lait, L. R., et al.: An assessment of the ozone loss during the 1999-2000 SOLVE/THESEO 2000 Arctic campaign, J. Geophys. Res., 107(D20), 8261, doi:10.1029/2001JD000412, 2002.

Sugita, T., Yokota, T., Nakajima, H., et al.: Validation of ozone measurements from the Improved Limb Atmospheric Spectrometer, J. Geophys. Res., 107(D24), 8212, doi:10.1029/2001JD000602, 2002.

Thompson, A. M., Witte, J. C., McPeters, R. D., et al.: Southern Hemisphere Additional Ozonesondes (SHADOZ) 1998-2000 tropical ozone climatology 1. Comparison with Total Ozone Mapping Spectrometer (TOMS) and groundbased measurements, J. Geophys. Res., 108, D2, 8238, doi:10.1029/2001JD000967, 2003.

Tsou, J. J., B. J. Connor, A. Parrish, I. S. McDermid, and W. P. Chu: Ground-based microwave monitoring of middle atmosphere ozone: Comparison to lidar and Stratospheric and Gas Experiment II satellite observations, J. Geophys. Res., 100(D2), 3005-3016, 1995.

Tuck, A., Hovde, S., Kelly, K., Russell III, J., Webster, C., and May, R.: Intercomparison of HALOE and ER-2 aircraft H2O and $\mathrm{CH} 4$ observations collected during the second airborne arctic stratospheric experiment (AASE-II), Geophys. Res. Lett., 20(12), 1243-1246, 1993.

von der Gathen, P.: Data provided by the ENVISAT Validation data base (http://nadir.nilu.no/calval/), 2003.

von Friedeburg, C.: Derivation of Trace Gas Information combining Differential Optical Absorption Spectroscopy with Radiative Transfer Modelling, Dissertation Heidelberg, 2003.

Wagner, T., Bruns, M., Burrows, J. P., Fietkau, S., Finocchi, F., Heue, K.-P., Hönninger, G., Platt, U., Pundt, I., Richter, A., Rollenbeck, R., von Friedeburg, C., Wittrock, F., and Xie, P.: The AMAX instrument and its application for SCIAMACHY validation, Proceedings of the 15th ESA symposium on rocket and balloon program and related research, Biarritz, France, 28-31 May 2001, ESA SP-471, August 2001.

Wagner, T., Heland, J., Zöger, M., and Platt, U.: A fast $\mathrm{H}_{2} \mathrm{O}$ total column density product from GOME - validation with in-situ 
aircraft measurements, Atmos. Chem. Phys., 3, 651-663, 2003, SRef-ID: 1680-7324/acp/2003-3-651.

Waters, J. W., Read, W. G., Froidevaux, L., et al.: Validation of UARS Microwave Limb Sounder C1O measurements, J. Geophys. Res., 101 , D6 , 10 091-10 128 (95JD03351), 1996.
Wirth, M. and Renger, W.: Evidence of Large Scale Ozone Depletion Within the Artic Polar Vortex 94/95 Based on Airborne Lidar Measurements, Geophys. Res. Lett., 23, 813-816, 1998. 